Board of Governors of the Federal Reserve System

International Finance Discussion Papers

Number 765

May 2003

\title{
AN EMPIRICAL ANALYSIS OF INFLATION IN OECD COUNTRIES
}

\author{
Jane Ihrig and Jaime Marquez
}

NOTE: International Finance Discussion Papers are preliminary materials circulated to stimulate discussion and critical comment. References in publications to International Finance Discussion Papers (other than an acknowledgment that the writer has had access to unpublished material) should be cleared with the author or authors. Recent IFDPs are available on the Web at www.federalreserve.gov/pubs/ifdp/. 


\title{
AN EMPIRICAL ANALYSIS OF INFLATION IN OECD COUNTRIES
}

\author{
Jane Ihrig and Jaime Marquez
}

\begin{abstract}
One of the most remarkable macroeconomic developments of the past decade has been the widespread decline in inflation despite declines in unemployment rates. For the United States, these seemingly contradictory developments have been reconciled in terms of three factors: (1) an acceleration in productivity, (2) structural changes in labor markets that lowered the natural unemployment rate (NAIRU), and (3) improved credibility of monetary policy. Here we ask whether comparable factors were at work in foreign industrial countries. To address this question, we empirically characterize the relationship between inflation, the unemployment rate, and structural factors using an extended Phillips curve model with quarterly data through 1994. By undertaking counterfactual simulations from 1995 to 2001, we quantify the separate contributions of unemployment-rate movements, labor-market reforms (that affected the NAIRU), and productivity developments on inflation. In line with previous work on the United States, we find that productivity advancements were the main structural factor reducing inflation in the United States. For foreign countries, persistent labor-market slack was the main factor exerting downward pressure on inflation. This persistence stemmed, in part, from structural reforms that lowered the NAIRU while the unemployment rate was declining.
\end{abstract}

Keywords: Phillips Curve, Unemployment, NAIRU, Labor Productivity, Policy Credibility, Business Cycles, Model Simulations.

\footnotetext{
* Staff economists of the Division of International Finance of the Federal Reserve Board.We would like to thank Steven Kamin for numerous comments on the evolution of this paper; Flint Brayton, Jon Faust, David Lebow and Deb Lindner offered important suggestions that improved this version of the paper. We have also benefited from Olivier Blanchard, Oyvind Eitrheim, Neil Ericsson, Joe Gagnon, Joe Gruber, Bill Helkie, Karen Johnson, David Reifschenider, Nathan Sheets, Sandy Struckmeyer, and Bob Tetlow. We are especially grateful to Carter Hemphill for all his work; Marcus Loveland, Patti Teagle and Shing-Yi Wang also provided invaluable research assistance. The views in this paper are solely the responsibility of the authors and should not be interpreted as reflecting the views of the Board of Governors of the Federal Reserve System or of any other person associated with the Federal Reserve System.
} 


\section{Introduction}

One of the most remarkable macroeconomic developments of the past decade has been the widespread reductions in inflation despite declines in unemployment rates. For the United States, this seemingly counterintuitive reduction in inflation has been explained in terms of an acceleration in productivity, structural changes in labor markets that lowered the natural unemployment rate (NAIRU), and improved credibility of monetary policy. The question we ask here is whether these factors also played an important role in explaining the reduction in inflation in foreign industrial countries.

We begin our analysis in section 2 by summarizing data on inflation, unemployment, output, and productivity for 20 OECD countries. Inspection of the data suggests that economic slack abroad, instead of advances in productivity, explains how inflation declined while the unemployment rate fell. Specifically, productivity abroad had not accelerated and so it is unlikely to have exerted downward pressure on inflation. On the other hand, labor market reforms have exerted downward pressure on the NAIRU and, by keeping labor slack above what it would have been in the absence of such reforms, are likely to be the relevant factor in explaining the declines in inflation.

To examine this explanation more closely, we use a model linking inflation to its various determinants. Section 3 outlines the analytical framework we use to characterize the relationship between inflation, the unemployment rate, and structural factors. Specifically, we estimate an extended Phillips curve model allowing for a time-varying natural rate of unemployment and for unit-labor costs. We estimate the model with quarterly data through 1994, reserving observations from 1995 to 2001 for counterfactual simulations that quantify the relative importance of each of these factors. These counterfactual simulations are implemented in section 4. For the United States, we find productivity advancements to be the main explanation for reconciling the puzzling declines of both inflation and unemployment in the latter part of the 1990s; this finding is consistent with previous work. For most foreign industrial countries, we find support for the idea that labor-market reforms

exerted downward pressure on the NAIRU, which kept the declining unemployment rate above the 
NAIRU in most countries and prolonged labor market slack.

Although we examine monetary policy's role in reducing inflation since 1995, we cannot determine how much of an effect this increase had on inflation. Appendix (6.1) discusses our evidence of increased credibility of monetary policy and our attempts to measure the effect on inflation.

\section{Explaining Foreign Inflation}

Figure 1 compares developments in inflation and unemployment for 20 OECD countries over the past several decades; appendix (6.2) has the details of the data series. As shown, the quarterly headline inflation rate (at an annual rate) has fallen in most industrial countries in the 1990s relative to the previous decades. Similarly, unemployment has come down relative to early highs as well. Table 1 compares inflation in the first half of the 1990s-their averages for 1990-94-with their averages for 1995-2001. As indicated, inflation rates fell for most countries over the latter half of the 1990s; the median decline in foreign inflation is 1.1 percentage points; these declines occurred despite the boost to inflation rates in 2000-2001 from high energy prices. Table 2 shows that the unemployment rate fell over the same period inflation was declining. Indeed, the average unemployment rate at the end of the decade, averaged over 1999-2001, fell 1.5 percentage points when compared with its average in the 1990-94 period.

Hence, as with the U.S. experience, the question arises as to why inflation in foreign industrial economies declined in the latter half of the 1990s, even as the unemployment rate was falling. To address this question, we consider a simple framework in which inflation depends on inflation expectations, and on the difference between the unemployment rate and the NAIRU:

$$
\pi_{t}=\beta_{0}+E_{t} \pi_{t+1}-\beta_{1} \cdot\left(U_{t}-U_{t}^{*}\right)+\epsilon_{t},
$$

where $\pi$ is the inflation rate, $U$ is the unemployment rate, $U^{*}$ is the NAIRU, and $\epsilon$ is an error term. This simple framework suggests several explanations for the anomalous coincidence of falling 
inflation and falling unemployment rates since 1994.

\subsection{Explanations involving labor market conditions}

First, it is possible that in some countries, the unemployment rate started out sufficiently above the NAIRU such that, even after declining significantly over the period, on average it remained above the NAIRU. This is the simplest explanation of how inflation might have fallen at the same time as the unemployment rate. It involves no structural changes, as neither the NAIRU nor any other parameters or determinants of the relationship between inflation and unemployment change in this story. We refer to this explanation as the 'unemployment effect.'

Second, it is possible that in some countries the NAIRU declined even more than did the unemployment rate in the latter part of the 1990s, so that, again, the unemployment rate remained above its equilibrium level. Several factors might account for a decline in the NAIRU. In the United States, as pointed out by Ball and Mankiw (2002), structural changes in labor markets resulting from changes in demographics of the labor force or changes in government policies regarding disability insurance and incarceration have reduced the natural rate in recent years. In many foreign industrial countries, observers point to structural reforms of labor markets, based on increased employment flexibility including the use of fixed-term contracts and part-time employment, as lowering the natural rate of unemployment. We refer to this explanation as the 'NAIRU effect.'

One can combine the unemployment and NAIRU effects into the typical measure of labormarket slack : the difference between the unemployment rate and NAIRU. Labor-market slack can change over time as the unemployment rate moves or the NAIRU changes, or both. ${ }^{1}$

Figure 2 summarizes labor market conditions for many industrial countries over the past decade. The first panel illustrates that, in the early 1990s, the U.S. unemployment rate was well above the OECD's current estimate of the NAIRU. However, labor-market slack began to diminish in 1992, and by 1997 the unemployment rate was below the NAIRU, indicating relatively tight labor markets. The next panel shows our GDP-weighted measures of the unemployment rate and the corresponding

\footnotetext{
${ }^{1}$ Changes in the NAIRU can affect the unemployment rate but we abstract from this complication.
} 
NAIRU for the 19 foreign industrial countries in our study. As a bloc, foreign economies experienced relatively slack labor markets through the end of the period, as the average unemployment rate remained above the NAIRU. The evolution of labor-market slack in the euro area also shows that the actual unemployment stayed well above a fairly flat NAIRU throughout most of this period. By contrast, in the United Kingdom, the sharp decline in the unemployment rate after 1992 would have left labor markets much tighter had it not been for significant NAIRU declines. In both cases, labor-market slack is a likely factor explaining the decline of foreign inflation.

To assess the role that slack in labor markets played in lowering inflation, figure 3 presents a scatterplot of the annual average (1995-2000) for the unemployment rate minus the NAIRU against the change in the inflation rate between the mid-1990s (1993-95) and the end of the 1990s (19992001). Slack in the labor market is indicated by a positive value of the unemployment gap. The significant negative correlation between the series, as indicated by the fitted line, implies that the greater was the amount of slack in the labor market in the latter half of the decade, the greater was the fall in inflation during this period. Nearly all countries conform to this view.

NAIRUs are, of course, notoriously hard to estimate. An alternative measure of slack in the economy is the difference between the level of GDP and its estimated potential level-the output gap. Figure 4 plots the average output gap estimates from 1995 to 2001 against changes in the average inflation rates between the mid-1990s and the end of the 1990s. As shown, the greater the excess capacity in an economy in the latter half of the decade, the greater was the fall in the rate of inflation. Hence, both measures of slack tell much the same story: many foreign countries, in contrast to the United States, had excess production capacity or labor-market slack that helped to keep inflation rates low in the latter part of the 1990s.

\subsection{Explanations involving productivity growth}

In addition to factors involving unemployment and the NAIRU, it is possible that some other determinants of inflation, not explicitly noted in our equation above, might have changed during the 1990s. Ball and Moffit (2001) highlight the role of the acceleration of productivity in the United 
States in reducing inflation even as unemployment rates declined. They argued that, because the rise in productivity growth was not immediately incorporated into higher wage growth, unit-labor costs declined putting downward pressure on prices.

Could this third explanation for why inflation fell have been relevant to foreign countries? Table 3 compares the estimated growth rate of both labor productivity and multi-factor productivity for a subsample of the 20 countries in our sample; these data are from Gust and Marquez (2000). The productivity measures correspond to economic activity in the business sector and are collected by the OECD. These data indicate that compared to the first half of the 1990s, only two foreign industrial countries experienced an acceleration in labor productivity in the second half of the 1990s: Australia and France; for multi-factor productivity, six foreign industrial countries experienced an increase in their growth rates. Hence, an initial look at the data suggests that an acceleration in productivity is not a likely explanation of the decline in inflation abroad.

\subsection{Explanations involving monetary policy credibility}

A fourth explanation for why inflation might have fallen is that the credibility of monetary policy might have increased. In the foreign countries, this could have reflected several factors, including the run-up to EMU in European countries, the adoption of inflation-targeting in other countries, and more generally, the adoption of a "get-tough" attitude toward inflation since the early 1980s. ${ }^{2}$ An improvement in credibility might have had the benefit of lowering and more tightly anchoring inflation expectations. Referring to our equation above, not only might this have lowered inflation directly, by reducing inflation expectations. With inflation expectations better anchored as agents expected monetary authorities to keep future inflation under control, declines in unemployment might have been less likely to raise inflation.

One way of testing for an increase in monetary policy credibility is by examining estimates of the responsiveness of monetary policy to inflation, derived from estimated Taylor rules. Specifically,

\footnotetext{
${ }^{2}$ See Bernanke, Laubach, Mishkin, Posen (1999) for more details on the effects of inflation targeting regimes on the rate of inflation.
} 
we use results from Gagnon and Ihrig (2001) who estimate Taylor rules for two sample periods for each country; the country-specific sample breaks are listed in the third column of Table 4. The first period is a time when monetary policy is believed to be less credible than in the second sample period and, typically, the first sample depicts a period of high and volatile inflation. For the United States, the sample is split at 1980, immediately after the appointment of Paul Volcker to the Federal Reserve. For many European countries the sample is split at 1987, around a major EMS realignment. Most inflation targeting countries have their sample split at the onset of their inflation targeting regime.

Table 4, columns 1 and 2, present the coefficients on inflation from estimated Taylor rules for the two sample periods. We see that in 14 out of 20 countries, including the United States, the coefficient on inflation in an estimated Taylor rule rose between approximately the mid-1980s, column 1, and the mid-1990s, column 2. This suggests a basis for improved monetary policy credibility as of late. However, it is important to keep in mind that this measure of credibility will show an increase in credibility whenever policy shifts to a more anti-inflationary stance (whether or not this is associated with increased credibility). Hence, the extent to which higher credibility actually rose is difficult to assess. Appendix (6.1) reports results using an alternative approach to measure monetary policy credibility that focuses on its effect on the responsiveness of inflation to the gap between unemployment and the NAIRU $\left(\beta_{1}\right)$.

\subsection{Summary}

This examination of the data provides several preliminary assessments regarding the causes of disinflation abroad. First, the stance of labor markets likely played a much different role in the decline in inflation abroad compared with that in the United States. On average over 1995-2001, the U.S. labor market appeared to be tight so that, in the absence of other factors, it would have put upward pressure on inflation. Conversely, in most foreign industrial economies, continued slack in labor markets probably accounts for some of the disinflation observed in the latter half of the 1990s. While unemployment rates fell, they did so from high levels; they sometimes did not fall 
until later in the 1995-2001 period, while the NAIRUs edged down as well.

Second, most foreign industrial countries did not show signs of productivity gains over the latter part of the 1990s. This is in stark contrast to the United States where there is compelling evidence of productivity gains. Hence, finding evidence that productivity was a large factor in pushing down inflation in foreign countries in the latter 1990s does not seem likely. Third, we find preliminary evidence of an increase in the credibility of monetary policy through explicit or implicit inflation targeting.

\section{Empirical Analysis}

The examination of the data above, though suggestive, is largely conjectural. To help us distinguish more precisely the factors contributing to disinflation abroad, this section estimates the parameters of an inflation model widely used in the literature. We postulate that, in the long-run, the CPI level is determined by unit labor costs but that, in the short run, movements in economic activity and deviations of the CPI from its long-run tendency will affect the inflation rate; we allow the natural unemployment rate to change over time. This approach has been implemented by Gali and Gertler (1999), Gordon (1998), and Gruen, Pagan, and Thompson (1999).

\subsection{Model Specification}

We model inflation as:

$$
\pi_{t}=\beta_{0}+\beta_{1}(L) \pi_{t-1}+\beta_{2}(L)\left(U_{t}-U_{t}^{*}\right)+\beta_{3}(L) \log \left[\frac{C P I}{\text { Mprice }}\right]_{t-1}+\beta_{4}(L) \log \left[\frac{C P I}{U L C}\right]_{t-1}+\epsilon_{t}
$$

where $\pi$ is the quarterly inflation rate (s.a.a.r.) of the consumer price index $(C P I), L$ is the lag operator, Mprice is the import price index, $U L C$ is unit labor costs, and $\epsilon_{t} \sim N\left(0, \sigma^{2}\right) .{ }^{3}$ Equation (1) captures current advances in modeling inflation which incorporate structural changes in labor

\footnotetext{
${ }^{3}$ The equation may include dummy variables for tax changes or German unification.
} 
markets, through $U^{*}$, and productivity, through $U L C .{ }^{4}$ Equation (1) assumes the inflationary expectations are formed on the basis of past inflation rates-that is, $E_{t} \pi_{t+1}=\beta_{1}(L) \pi_{t-1}$. We restricted the coefficients on lagged inflation to sum to one so that the equation can be interpreted as saying that, in the long run, when the unemployment rate is at its natural rate, the inflation rate is not changing. ${ }^{5}$ We expect the sum of the coefficients on the unemployment gap to be negative: the higher the unemployment rate relative to the NAIRU the less price pressure. The coefficient on the relative import price term should also be negative, since an increase in import prices, which is in the denominator, should raise prices. This term also incorporates the effects of variations in imported energy prices. The sum of the coefficients on real unit-labor costs ought to lie between zero and minus one.

We measure the NAIRU in two ways: with OECD data and with an H-P filter applied to the data on the unemployment rate. In addition, we replace $U_{t}-U_{t}^{*}$ with $\left(Y_{t}-Y_{t}^{*}\right) / Y_{t}^{*}$ where $Y_{t}$ is real GDP and $Y_{t}^{*}$ is potential output estimated in two ways: as moving average or as an H-P filter of GDP. Overall, there are four formulations for each country.

\subsection{Estimation Results}

We use quarterly observations ending in 1994Q4 to estimate the parameters of equation (1) for each country; the start date for the sample varies across countries but, in general, it begins in the mid-1970s. By ending the sample estimation in 1994Q4, we can study whether subsequent (or on-going) structural changes altered the inflation process in the 1995-2001 period.

In estimating the parameters of equation (1), we apply a general-to-specific strategy. That is,

\footnotetext{
${ }^{4}$ In terms of time-series properties, we find trends in $\pi, \log \left[\frac{C P I}{U L C}\right]$, and $\log \left[\frac{C P I}{M \text { price }}\right]$. Technically, using the ADF statistic, we cannot reject the hypothesis that these series are non-stationary. Note, however, that tests of stationarity are known for not being powerful against relevant alternatives.

${ }^{5}$ In interpreting this equation, some subtle issues arise regarding the time series properties of the variables. Because we impose that the coefficients on lagged inflation add up to one, the left hand side variable is effectively the change in inflation, which is stationary. The two relative price variables on the right hand side may be nonstationary (we cannot reject this). Of course, unit root tests have low power and these relative prices may in fact be stationary. Even if the right hand side variables are nonstationary, because we include lags of these variables, the typical standard errors on the individual coefficients remain appropriate; see Sims, Stock, and Watson (1990). Intuitively, the estimates are free to imply that these nonstationary variables only enter in differences.
} 
we start by estimating a regression with 8 lags of inflation and 4 lags of each other independent variable. Then we remove variables whose coefficients are deemed to be too small (via T-statistics), but always imposing the constraint that the lagged inflation coefficients to sum to one. ${ }^{6}$

To assist in this process of selection we seek to satisfy:

- coefficient signs that are consistent with theory,

- parameters that are stable throughout the estimation sample, and

- residuals consistent with normality, serial independence, homoskedasticity. ${ }^{7}$

If these conditions are met, we proceed to exclude insignificant coefficients one at a time and retest for residual properties and parameter stability as the process of simplification proceeds; appendix (6.3) documents the various parameter-constancy tests.

Table 5 reports, for each country, the sum of the estimated coefficients, the standard errors of the coefficient sums, and tests on the error terms for each of the four models. In many cases, sums of the coefficients may not be significantly different from zero, even though individual coefficients (not shown) are significant. For most country regressions, looking across labor-market slack measures, we see only slight difference in the parameter estimates, suggesting the results are not sensitive to the specific measure of labor-market slack. But looking at the properties of the regressions, we find that the specification relying on the OECD measure of the NAIRU is the one offering the fewest violations to our selection criteria. Specifically, for the alternative measure of the NAIRU, or for the measure of slack based on potential output, the sign violations (across all exogenous variables)

\footnotetext{
${ }^{6}$ Meaningful tests of this long-run restriction require estimation samples longer than the ones available to us. Thus one should not be surprised to find a lack of universal empirical support for this restriction. We found that the data cannot reject this restriction in six countries, the United States being one of them. Of the countries for which this restriction is at odds with the data, Germany, New Zealand, and Switzerland have the lowest sum of lagged coefficients (0.4). For the majority of the other countries, the sum of lagged coefficients on inflation is 0.7 or higher.

${ }^{7}$ We test for normality using the Jarque-Bera test statistic which is distributed as $\chi^{2}(2)$. For joint serial independence, we apply an F-test to the hypothesis that the coefficients for a AR(5) of the estimation residuals are jointly equal to zero. For the hypothesis of homoskedasticity, we use an ARCH test. See Hendry and Doornik (1999) for details.
} 
are more numerous. Since the proper sign is key to our out-of-sample analysis, we focus on the estimated model using labor-market slack with the OECD's NAIRU.

For the OECD-based measure of the NAIRU we find a negative coefficient on the sum of unemployment rate terms for all countries; in half of these the coefficients are significant. The sum of the coefficients on real unit-labor costs is only significant in Belgium and the United States. In six countries this term dropped out of the model, suggesting that productivity was not important in explaining the movement of inflation for these countries. The estimation results cannot reject the hypotheses of serial independence, except in Australia, Germany, and the United Kingdom; we cannot reject homoskedasticity except in Australia and Japan; we cannot reject normality in nine cases. Finally, we cannot reject the hypothesis of parameter stability; see table A1.

\subsection{Model Reliability}

To assess the reliability of the estimates, we consider two approaches. First, we generate one-step ahead forecasts of inflation from 1995Q1 onwards and test whether the forecast errors are zero. The forecast horizon ends in 2002Q1 except in a few countries where the ending date is 2000Q4 due to data constraints. Second, we examine whether the standard Phillips curve can trace movements in the rate of inflation beginning in the mid-1990s. To the extent that such standard models are able to explain the low inflation of the latter 1990s fairly well, this would lend support to the view that disinflation in foreign industrial countries was attributable to standard factors such as the unemployment effects rather than to structural shifts in the process determining inflation included in equation (1). Conversely, if standard models tend to overpredict inflation, then structural factors shifting the Phillips curve downward could be important.

Determining the degree of forecast accuracy involves testing for systematic bias in the forecasts. To this end, we generate one-step ahead forecast errors (actual minus predicted) and test the null hypothesis that their mean is zero. Table 6 reports the mean forecast error and the Z-statistics for the zero innovation mean $;^{8}$ figure 5 shows the mean forecast error for all countries. For the

\footnotetext{
${ }^{8}$ This statistic is calculated as the ratio of the equation's standard error to the mean forecast error adjusted by
} 
United States, equation (1) overpredicts inflation, on average, by 0.33 percentage points (a.r.) per quarter. For the foreign countries, there is tendency to underpredict inflation though most these underpredictions are not statistically significant; the exceptions are Belgium, France, Germany, Greece, and Japan.

To assess whether the standard Phillips curve factors suffice to explain the weakness of foreign inflation in the late 1990s, or whether changes in the structure of the labor market and in productivity growth also were important, we postulate:

$$
\pi_{t}=\beta_{0}+\beta_{1}(L) \pi_{t-1}+\beta_{2}(L) U_{t}+\beta_{3}(L) \log \left[\frac{C P I}{\text { Mprice }}\right]_{t-1}+\epsilon_{t}
$$

where the NAIRU is assumed to be a constant (its value is embedded in $\beta_{0}$ ) and changes in productivity growth do not influence the rate of inflation directly.

Applying the general-to-specific methodology to equation (2), we find, in general, a poor fit: the sum of the coefficient estimates for the unemployment rate is negative for 18 of the 20 countries but significant in 4 - New Zealand, Portugal, Sweden and the United States; the detailed results are reported in Table A2. Table 6 reports the one-step ahead mean forecast error for equation (2) during 1995Q1-2001Q4. We find the equation overpredicts inflation in nine countries, although this overprediction is statistically significant only for the United States and New Zealand, and underpredicts inflation for the other countries in the sample, of which three cases are statistically significant.

Looking at forecasting errors across equations (1) and (2) reveals that allowing for productivity in the Phillips curve model does not do much for predicting inflation in the foreign economies, but it does help reduce the forecast error in the United States. This observation suggests that the explanations for reducing inflation in the latter part of the 1990s in foreign industrial countries are different from those applicable to the United States. Indeed, labor-market slackness appears as the relevant explanation for the weakness of inflation in foreign economies during the latter half the square root of the number of forecast observations. 
of the 1990s. In order to quantify more precisely the separate contributions of these factors to the evolution of inflation in the 1995-2002 period, we use equation (1) to conduct counterfactual simulations; appendix (6.1) examines the effect of credibility in monetary policy on inflation.

\section{Counterfactual Simulations}

\subsection{Scenario Design}

Our goal is to offer a decomposition of the relative importance of the factors responsible for movements in the inflation rate: changes in the natural rate of unemployment, changes in productivity, and changes in the unemployment rate. To quantify the relative importance of the these factors in reducing inflation, we implement four, one step-ahead, simulations:

1. Baseline: Predicted inflation using actual values of all explanatory variables in equation (1); we denote this path as $\pi^{B}$.

2. Constant NAIRU: Predicted inflation assuming that the NAIRU remains at its 1994Q4 value. We denote this constant NAIRU as $\bar{U}^{*}$ and the corresponding inflation path as $\pi^{*}$ :

$$
\pi_{t}^{\bar{U}^{*}}=\beta_{0}+\beta_{1}(L) \pi_{t-1}+\beta_{2}(L)\left(U_{t}-\bar{U}^{*}\right)+\beta_{3}(L) \log \left[\frac{C P I}{\text { Mprice }}\right]_{t-1}+\beta_{4}(L) \log \left[\frac{C P I}{U L C}\right]_{t-1}
$$

3. Constant NAIRU and productivity growth: Predicted inflation assuming that the NAIRU remains at its 1994Q4 value and that labor productivity growth remains at its 1994 value. Changes in assumptions about productivity are introduced by changing the evolution of the unit labor cost via the term $\log \left[\frac{C P I}{U L C}\right]$. Specifically, the counterfactual unit-labor path is

$$
U L C^{c f}=\frac{\text { observed nominal wages }}{\text { counterfactual labor productivity }},
$$

where counterfactual labor productivity grows at the fixed, 1994 growth rate of labor pro- 
ductivity. We denote the resulting inflation path as $\pi^{S}$ :

$$
\pi_{t}^{S}=\beta_{0}+\beta_{1}(L) \pi_{t-1}+\beta_{2}(L)\left(U_{t}-\bar{U}^{*}\right)+\beta_{3}(L) \log \left[\frac{C P I}{M p r i c e}\right]_{t-1}+\beta_{4}(L) \log \left[\frac{C P I}{U L C^{c f}}\right]_{t-1} .
$$

4. No labor slack: Predicted inflation assuming that the unemployment gap is zero; ${ }^{9}$ we denote the resulting inflation path as $\pi^{U=U^{*}}$ :

$$
\pi_{t}^{U=U^{*}}=\beta_{0}+\beta_{1}(L) \pi_{t-1}+\beta_{3}(L) \log \left[\frac{C P I}{\text { Mprice }}\right]_{t-1}+\beta_{4}(L) \log \left[\frac{C P I}{U L C}\right]_{t-1}
$$

Before discussing the results, we want to emphasize that we do not have a general equilibrium model. In other words, our simulated inflation paths are a partial-equilibrium accounting exercise in which changing the path of certain variables does not take into account the indirect effects of such changes on other determinants of inflation. For example, if productivity growth is lowered in the counterfactual, then one would expect lower wage growth, with a corresponding effect on prices. The counterfactual in the paper does not allow the wage response, however, and the absence of this channel therefore overstates somewhat the impact on inflation.

With these considerations in mind, we use the four scenarios to quantify the effects of the factors in lowering inflation in the late $1990 \mathrm{~s}^{10}$

1. NAIRU effect: Estimate of the effect of changes in the NAIRU, on inflation. This effect is computed as the difference between the inflation path assuming that the NAIRU is constant $\left(\pi^{*}\right)$ and the baseline inflation path $\left(\pi^{B}\right)$. One can visualize this effect by subtracting equation (1) from equation (3):

$$
\pi^{\bar{U}^{*}}-\pi^{B}=\beta_{2}\left(U^{*}-\bar{U}^{*}\right),
$$

\footnotetext{
${ }^{9}$ We gradually reduce the unemployment gap to zero over 4 quarters, starting at the beginning of 1995 .

${ }^{10}$ To gauge the actual impact of changes in NAIRUs and productivity growth on inflation, it may be more accurate to compare the counterfactual inflation simulations with the baseline ex-post forecasts of the model rather than with actual inflation, since the difference between the counterfactual simulation and actual inflation not only includes the estimated effect of the counterfactual assumptions, but any errors in the baseline forecast.
} 
where $\beta_{2}<0$. Thus if the natural rate declines relative to its 1994 value $\left(U_{t}^{*}<\bar{U}^{*}\right)$, then $\pi^{\bar{U}^{*}}-\pi^{B}>0$ meaning that the inflation rate would have been higher had the decline in the NAIRU not taken place.

2. Productivity effect: Estimate of the effect of changes in productivity growth on inflation. This effect is computed as the difference between the inflation path assuming that both the NAIRU and productivity growth structural factors are constant $\left(\pi^{S}\right)$ and the inflation path assuming that only the NAIRU is constant $\left(\pi^{*}\right)$. One can visualize this effect by subtracting equation (3) from equation (4):

$$
\pi^{S}-\pi^{U^{*}}=\beta_{4}\left(\log U L C-\log U L C^{c f}\right),
$$

where $\beta_{4}<0$. Thus if counterfactual productivity growth is smaller than actual productivity growth $\left(\log U L C<\log U L C^{c f}\right)$, then $\pi^{S}>\pi^{\bar{U}^{*}}$. In that case, the inflation rate would have been higher had the increase in productivity growth not taken place.

3. Labor-slack effect: Estimate of the contribution of movements of labor slack $\left(U_{t}-U_{t}^{*}\right)$ on inflation. This effect is computed as the difference between the baseline inflation, $\pi^{B}$, and the "no-slack" inflation, $\pi^{U=U^{*}}$. One can visualize this effect by subtracting equation (5) from equation (1):

$$
\pi^{B}-\pi^{U=U^{*}}=\beta_{2}\left(U-U^{*}\right)
$$

where $\beta_{2}<0$. If a country has positive slack $\left(U-U^{*}>0\right)$, as in many European countries and Japan, then one would expect that a counterfactual elimination of that slack would raise inflation relative to baseline inflation-that is, $\pi^{B}<\pi^{U=U^{*}}$. Alternatively, if a country has negative slack, such as the United States, one would expect that a counterfactual elimination of that slack would lower the inflation relative to baseline inflation-that is, $\pi^{B}>\pi^{U=U^{*}}$. 


\subsection{Simulation Results}

Figure 6 shows the four simulated inflation series for the United States. The inflation path holding the NAIRU and productivity growth constant $\left(\pi^{S}\right)$ lies above all other inflation paths. This finding suggests that changes in these two structural factors helped reduce inflation in the late 1990s. The difference between the inflation paths associated with holding the NAIRU constant only $\left(\pi^{*}\right)$ and baseline inflation $\left(\pi^{B}\right)$ is the NAIRU effect; the gap between $\pi^{S}$ and $\pi^{\bar{U}^{*}}$ is the productivity effect. According to the results, $\pi^{S}>\pi^{U^{*}}$ meaning that inflation would have been higher had the acceleration in U.S. productivity not taken place. Moreover, the proximity of $\pi^{\bar{U}^{*}}$ to $\pi^{B}$ suggests that the NAIRU effect is small. ${ }^{11}$ Finally, the tightness in the U.S. labor market was exerting upward pressure on U.S. inflation through the latter half of the 1990s as one can see by the no labor-slack inflation path $\left(\pi^{U=U^{*}}\right)$ being below $\pi^{B}$ over most of the simulation.

Figure 7 shows the results for Ireland where we find the path for $\pi^{S}$ lies distinctly above $\pi^{B}$, suggesting that inflation would have been higher had the NAIRU and productivity growth remained constant at their 1994 values. We find that the gap between $\pi^{S}$ and $\pi^{*}$ (productivity effect) is smaller when compared to the the gap between $\pi^{*}$ and $\pi^{B}$ (NAIRU effect). This differential suggests that, unlike the U.S. experience, the decline in Irish inflation can be explained by movements in the NAIRU, and not productivity advancements. Finally, labor-market slack played a minimal role in lowering Irish inflation through 1998, as the unemployment rate was near the NAIRU. Since then, however, declines in the unemployment rate have outpaced declines in the NAIRU and the excess of $\pi^{B}$ over $\pi^{U=U^{*}}$ measures the corresponding inflationary effect.

Figure 8 shows the results for Netherlands. We find that the gap between $\pi^{S}$ and $\pi^{U^{*}}$ (productivity effect) is negligible compared to the the gap between $\pi^{\bar{U}^{*}}$ and $\pi^{B}$ (NAIRU effect). These findings suggest that in the absence of the increased labor-market flexibility, the Dutch inflation rate would have been higher than the one observed.

Figure 9 summarizes how structural factors affected inflation in the latter part of the 1990s for

\footnotetext{
${ }^{11}$ This result is due to the relatively small decline of the OECD's estimate of the NAIRU during the latter half of the 1990s. However, we find similarly small results with other measures of the NAIRU for the United States.
} 
each of the 20 countries. The green-solid bars are the average of the difference between $\pi^{B}$ and $\pi^{S}$. A negative entry means that the counterfactual inflation rate excluding the role of NAIRU and productivity exceeded the baseline inflation, suggesting that structural factors helped to push inflation down. The green-slanted bars represent the average NAIRU effect, measured as the average deviation between $\pi^{B}$ and $\pi^{\bar{U}^{*}}$. By comparing the green-slanted bars with the solid bars one can assess the relative importance of labor market reforms and productivity advancements on inflation.

Taken together, the results suggest that movements in the NAIRU and productivity contributed to the decline of inflation in 13 countries, including the United States. The amount that these two factors pushed inflation down per quarter ranges from 3.1 percentage points (a.r.) for New Zealand to 0.2 percentage points (a.r.) for the United Kingdom. For the United States, we find that these two factors reduce inflation, on average, by 0.5 percentage points (a.r.). In addition, advances in productivity account for the bulk of the decline in U.S. inflation rate since 1994. Ireland is the only other country where productivity advances exerted substantial downward pressure on inflation. For the remaining European countries, the downward pressure on inflation stems solely from declines in the natural rate of unemployment. Indeed, for some countries, movement in the NAIRU influenced the rate of inflation greatly. For example, in New Zealand, the results indicate that had its NAIRU not declined, its annual inflation rate would have exceed the respective baseline inflation rates, on average, by 3.1 percentage points. For Japan, we find that if their NAIRU had not increased, then Japanese inflation would have been lower, on average, by 2.7 percentage points.

Table 7 reports the estimated effect of labor-market slack on inflation between 1995 and 2001. As shown, the average of the difference between baseline inflation, $\pi^{B}$, and inflation in the no-slack scenarios, $\pi^{U=U^{*}}$, is negative for most countries. These negative entries indicate that, on average, labor-market slack exerted downward pressure on inflation rates in the latter 1990s. As an example, the results indicate that if there were no labor-market slack in either Japan or Germany, then their quarterly inflation rates would have been higher, on average, by 2.3 percentage points (a.r.) for Japan and 1.3 percentage points (a.r.) for Germany (table 7, column 1).

This labor-market slack effect can be decomposed into an effect due to changes in the NAIRU 
and an effect due to changes in the unemployment rate. Column 2 reports the NAIRU effect measured as the average of the difference between $\pi^{B}$ and $\pi^{\bar{U}^{*}}$. Column 3 reports the unemployment effect measured as the difference between the total and NAIRU effects. Turning to the NAIRU effect, we see substantial differences across countries. In Japan there is upward pressure on inflation as the rise in the NAIRU reduced labor-market slack. Alternatively, New Zealand's decline in its NAIRU helped to push quarterly inflation down over 3 percentage points (a.r.). Focusing on the unemployment effects, the results for Japan indicate that the rise in the unemployment rate alone exerted considerable downward pressure on inflation, nearly 5 percentage points (a.r.) on average (column 3). For Germany, another country with a rise in the unemployment rate, the results indicate a deflationary effect of 1.5 percentage points (a.r.). For Ireland, on the other hand, the results indicate that the pronounced decline in the unemployment rate (see figure 1) has exerted substantial upward pressure on the inflation rate, 2.3 percentage points (a.r.) on average.

Overall, we find that the decline in inflation rates across OECD countries does not have a single explanation. For the United States, the chief explanation is the acceleration in labor productivity. For foreign countries, structural reforms that affected the NAIRU and cyclical movements in the unemployment rate are responsible for the reduction in inflation. Hence the U.S. experience of an acceleration of productivity leading to a significant fall in inflation is apparently unique.

\section{Conclusion}

Comparing the early 1990s to the 1995-2001 period, we find rates of inflation declined in 18 industrial countries, including the United States, despite declines in unemployment rates. The question we address here is how to explain these declines in inflation. To this end, we estimate a model that allows for structural change in labor markets, developments in labor productivity and cycli-

cal changes in the unemployment rate. We conduct counterfactual simulations that enable us to quantify the effects of structural changes, as well as the more traditional measure of labor-market slack, on inflation in the latter 1990s. We find that the United States is the only country where 
an acceleration of productivity has played a major role in lowering the rate of inflation. For the majority of the remaining countries, the driving force was labor-market slack partly stemming from declines in the estimated NAIRU offsetting declines in the unemployment rate.

Finally, we find evidence consistent with the view that monetary policy has gained credibility in the latter half of the 1990s but were not able to identify a linkage between increases in monetary policy credibility and reductions in inflation.

\section{Appendixes}

\subsection{Monetary Policy Credibility}

One way that increased credibility can alter the Phillips curves is by decreasing the coefficient on the unemployment term. That is, enhanced credibility serves to anchor inflationary expectations so that they do not adjust quickly to temporary deviations of the unemployment rate from its natural level. To evaluate this possibility, we estimate equation (1) for each country in two separate sample periods. The first period is when monetary policy is believed to be less credible than in the second sample period. We then compare the coefficient on the employment gap term across the two regressions.

We estimate equation (1) for each of the subsamples listed in table 4, allowing all of the coefficient estimates to change. With these estimates, we calculate the change in the sum of the employment gap coefficients from the first sample to the second sample. Figure A2 plots the change in the sum of the employment gap coefficients, where a positive value means the sum of coefficients fell in value (i.e., became less negative). For 16 of the foreign countries, we find that the change in coefficient values is consistent with the view that an increase in the credibility of monetary policy lessened the link between inflation and the rate of unemployment. For the United States, the results do not support an increase in credibility.

If enhanced credibility of monetary policy played an important role in accounting for the declines in inflation rates across countries, one would expect to see a negative correlation between forecast 
errors from equation (1) and changes in the responsiveness of inflation to the unemployment gap. In other words, less negative coefficients on the unemployment rates (i.e., positive changes in this coefficient) should be associated with inflation being below its predicted value (i.e., negative forecast errors). To examine this hypothesis, we regressed the mean forecast errors of equation (1) over 1995-2001 (from Table 6) on the change in coefficient values from the first to second periods described above. We found these series to be positively correlated with each other rather than negatively correlated. This counterintuitive result may, in part, be due to the fact that equation (1) tended to underpredict rather than overpredict inflation for many countries, leaving nothing for improvements in credibility to explain. In any event, it suggests more research may be needed to quantify the linkages between monetary policy credibility and inflation behavior.

\subsection{Data}

We examine 20 industrial countries in this analysis: Australia, Austria, Belgium, Canada, Finland, France, Germany, Greece, Ireland, Italy, Japan, Netherlands, New Zealand, Norway, Portugal, Spain, Sweden, Switzerland, the United Kingdom, and the United States.

To estimate the parameters of our inflation equations we need data on the following variables: Consumer Price Indexes (CPI): To construct our measure of inflation we use the annualized quarterly change in the headline CPI. We focus on the headline CPI rather than the core CPI due to the lack of data on core inflation in many foreign countries. We use RPIX for the United Kingdom, which is retail prices excluding mortgage interest payments.

Unit Labor Costs $(U L C)$ : Data for unit labor costs come from the OECD database and measure

costs for the whole economy. The growth rate of $U L C$ is computed as $\frac{100\left(U L C_{t}-U L C_{t-1}\right)}{U L C_{t-1}}$ and is displayed in Figure A1. Cursory inspection of these growth rates reveals that unit labor costs have been growing at a fraction of the rates they exhibited in the 1980s. The experience of Australia, Ireland, Italy, Spain, and the United Kingdom underscore the depth of the change in this variable.

Import Price (Mprice): Data for import price are constructed as the product of the import unit value, in US\$, and the bilateral exchange rate. The observations come from the IMF International 
Finance Statistics.

Unemployment rate $(U)$ : For each country we use their standard definition of unemployment. Whether this includes or excludes military personnel differs by country.

NAIRU and unemployment gap $\left(U^{*}\right.$ and $\left.U-U^{*}\right)$ : In defining the unemployment gap we use two NAIRU measures. Our first measure uses OECD estimates; these data come from the OECD's Economic Outlook, June 2002 (No. 71). The OECD's NAIRUs are based on a two step procedure. First, the OECD applies a Kalman-filter to a model of inflation that yields a preliminary estimate of the natural rate. Second, these preliminary estimates of the NAIRU are adjusted judgmentally to allow for the effects of recent and on-going policy reforms, especially in Europe. The impact of these reforms on the NAIRU are typically found to be substantial, so that the OECD's estimate NAIRUs differ significantly from those that would be computed using Kalman filter procedure alone. ${ }^{12}$ Our second estimate of the NAIRU is constructed from H-P filtering the unemployment rate data. In general, these two alternative estimates of the NAIRU produce unemployment gaps that track each other quite closely.

Output Gap: In defining the output gap we use two alternative measures of potential. First we take a moving average of the previous twelve quarters' real GDP as the current quarter's measure of potential output. Second we use an H-P filter to back out a potential series.

Dummy variables:Changes in tax policy and German unification are captured with dummy variables.

\subsection{Parameter Stability}

What is important in the counterfactual simulations is to avoid the results being influenced by factors other than the counterfactual path for the exogenous variables. Parameter instability is one such factor we attempt to minimize. We test for parameter instability in equation (1), as described next, and then proceed to the discussion of the results from the counterfactual simulations.

\footnotetext{
${ }^{12}$ For example, the OECD (2001) notes that the econometric estimate of Ireland's NAIRU in 1999 was 9 percent, but they judgementally adjusted it to 7 percent.
} 
For parameter stability of equation (1) we use recursive Chow tests implemented in three steps:

1. Split the estimation sample at a particular date, $T$, and use the first subsample to obtain initial parameter estimates. The value of $T$ is set sufficiently large to allow for a precise estimation of the associated parameters. Thus, if the estimation sample is from 1977 to 1994 , then $T$ may be 1985 . Note that the value of $T$ differs across countries because of differences in the starting date of the estimation sample and the numbers of parameters to be estimated. In general, however, these tests examine the from the early 1980s to 1994.

2. Use these initial estimates to forecast inflation from $T+1$ through $T+N$, where $N$ is the number of forecast periods available. Continuing with the above example, if the estimation sample ends in 1994 and $T$ is 1985, then the forecast horizon extends nine years or 36 quarters.

3. Test whether the forecast errors are, on average, statistically equal to zero. A rejection of this hypothesis means that the parameters cannot be treated as constant between the first $T$ observations and the subsequent forecast period.

For a given initial estimation sample ending at $T$, we consider three forecast periods:

1. One period ahead: The equation, estimated through $T$, is used to forecast $T+1$, and a test of whether the forecast error is statistically equal to zero is conducted. The estimation estimation sample is then lengthened to $T+1$, a forecast error for $T+2$ is computed, and so on.

2. Expanding Horizon: the forecast involves $h$-periods ahead where the initial estimation period always ends at $T$ and the forecasting period always starts at $T$ and ends at $T+h$. The forecast period $h$ is progressively expanded from 1 to $N$.

3. Contracting Horizon: the estimation period initially ends at $T$ and is used to compute a forecast error for the period $T+1$ through $T+N$. Then, the estimation sample is extended 
through $T+1$, and the forecast period is reduced to $T+2$ through $T+N$. Thus, as the estimation sample increases, the forecast period decreases from $N$ to 1 .

Table A1 summarizes the test results in terms of the frequency of violations of parameter stability and the dates of these violations. An entry of "0" denotes no rejections of the hypothesis of parameter stability for the period considered. An entry of "+" denotes one or two rejections of the hypothesis of parameter stability for the period considered; "++" denotes at most a half-dozen rejections of the hypothesis of parameter stability; " +++ " denotes numerous rejections of the hypothesis of parameter stability. When the estimation sample ends in 1994, the results suggest overwhelming evidence of parameter stability-that is, there are a lot of zeroes; the one country where parameter instability is worrisome is Germany during 1983 and 1992.

We also repeat, as robustness, the parameter-stability tests when the estimation sample is extended to cover all of the remaining observations. In this case, we should expect a slight increase in the rejections of the hypothesis as the sample size increases. We find that the majority of the countries there is only a slight increase in the frequency of rejection. Therefore, our sense is that our estimates for equation (1) remained stable, on balance, during the simulation period, and hence is suitable to producing reliable counterfactual simulations.

\section{References}

Andersen, P. and W. Wascher, 2001, "Understanding the recent behavior of inflation : an empirical study of wage and price developments in eight countries," in Empirical Studies of Structural Changes and Inflation, BIS Papers No 3, 267-302.

Ball, L. and G. Mankiw, 2002, "The NAIRU in Theory and Practice," Journal of Economic Perspectives, 16, 115-136.

Ball, L. and R. Moffitt, 2001, "Productivity Growth and the Phillips Curve," NBER Working Paper No. w8421. 
Bernanke, B., T. Laubach, F. Mishkin, and A. Posen, 1999, Inflation Targeting, Princeton University Press, Princeton N.J.

Hendry, D. and J. Doornik, 1999, Empirical Econometric Modelling Using PcGive, Vol 1., Timberlake, London.

Gali, J. and M. Gertler, 1999, "Inflation Dynamics: A Structural Econometric Analysis," Journal of Monetary Economics, 44, 195-222.

Gagnon, J. and J. Ihrig, 2001, "Monetary Policy and Exchange Rate Pass-through," International Finance Discussion Paper No. 704.

Gordon, R., 1998, "Foundations of the Goldilocks Economy: Supply Shocks and the Time-Varying NAIRU," Brookings Papers on Economic Activity, No. 2, 297-346.

Gruen, D., A. Pagan, C. Thompson, 1999, "The Phillips Curve in Australia," Journal of Monetary Economics, 44, 223-258.

Gust, C. and J. Marquez, "Productivity Developments Abroad," 2000, Federal Reserve Bulletin, Vol. 86, 665-681.

Sims, C.A., J.H. Stock, and M.W. Watson 1990. "Inference in Linear Time Series Models with Some Unit Roots," Econometrica, 58:113-44.

Stock, J. and M. Watson, 1999, "Forecasting Inflation," Journal of Monetary Economics, 44, 293-335.

Turner, Dave et al., 2001, "Estimating the Structural Rate of Unemployment for the OECD countries," OECD Economic Studies, No 33. 
Figure 1

\section{Inflation and Unemployment Rates in Selected OECD Countries}
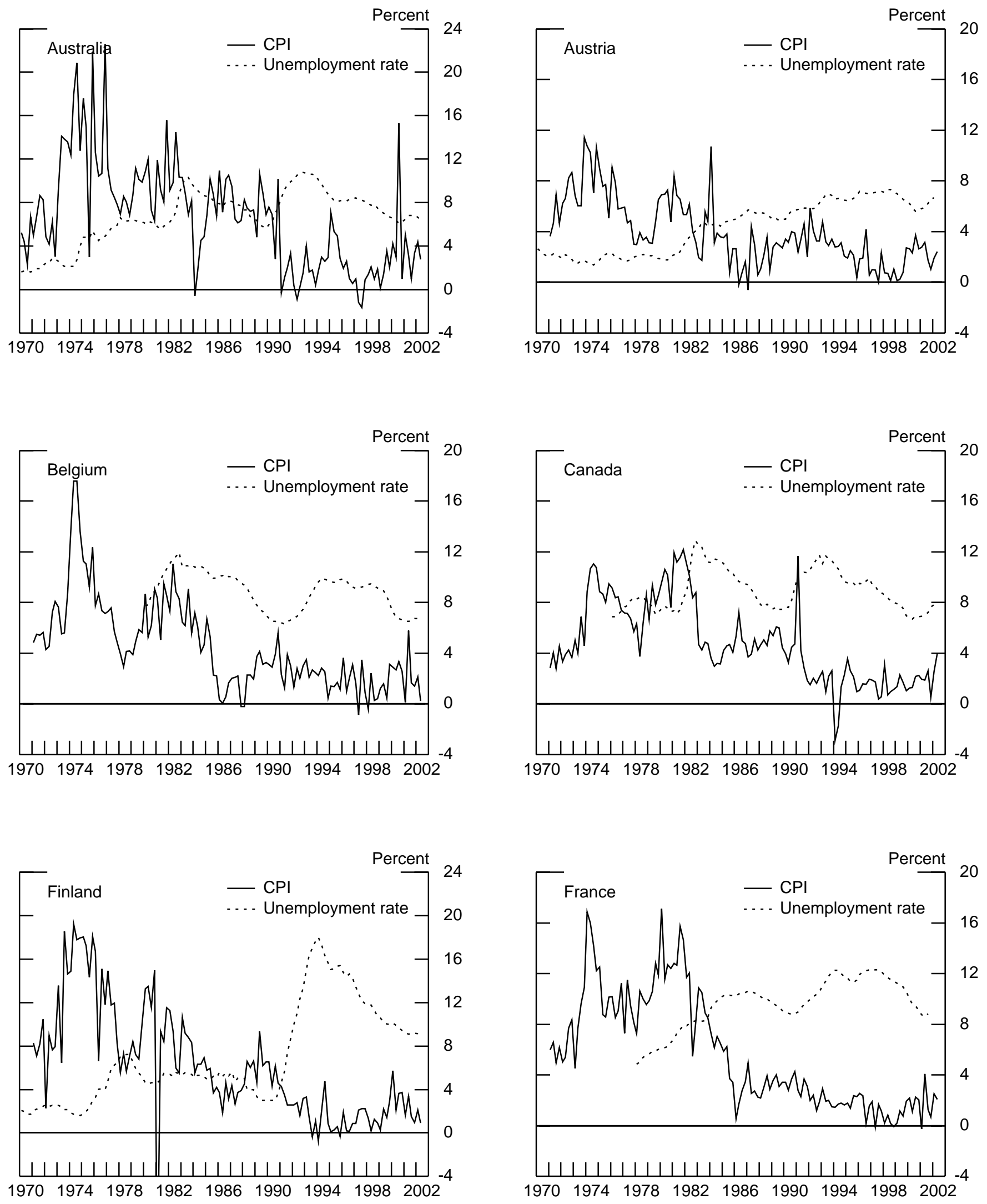

Inflation rates are quarterly (a.r.) growth rates of headline CPIs. Unemployment rates are quarterly averages. 
Figure 1

\section{Inflation and Unemployment Rates in Selected OECD Countries (continued)}
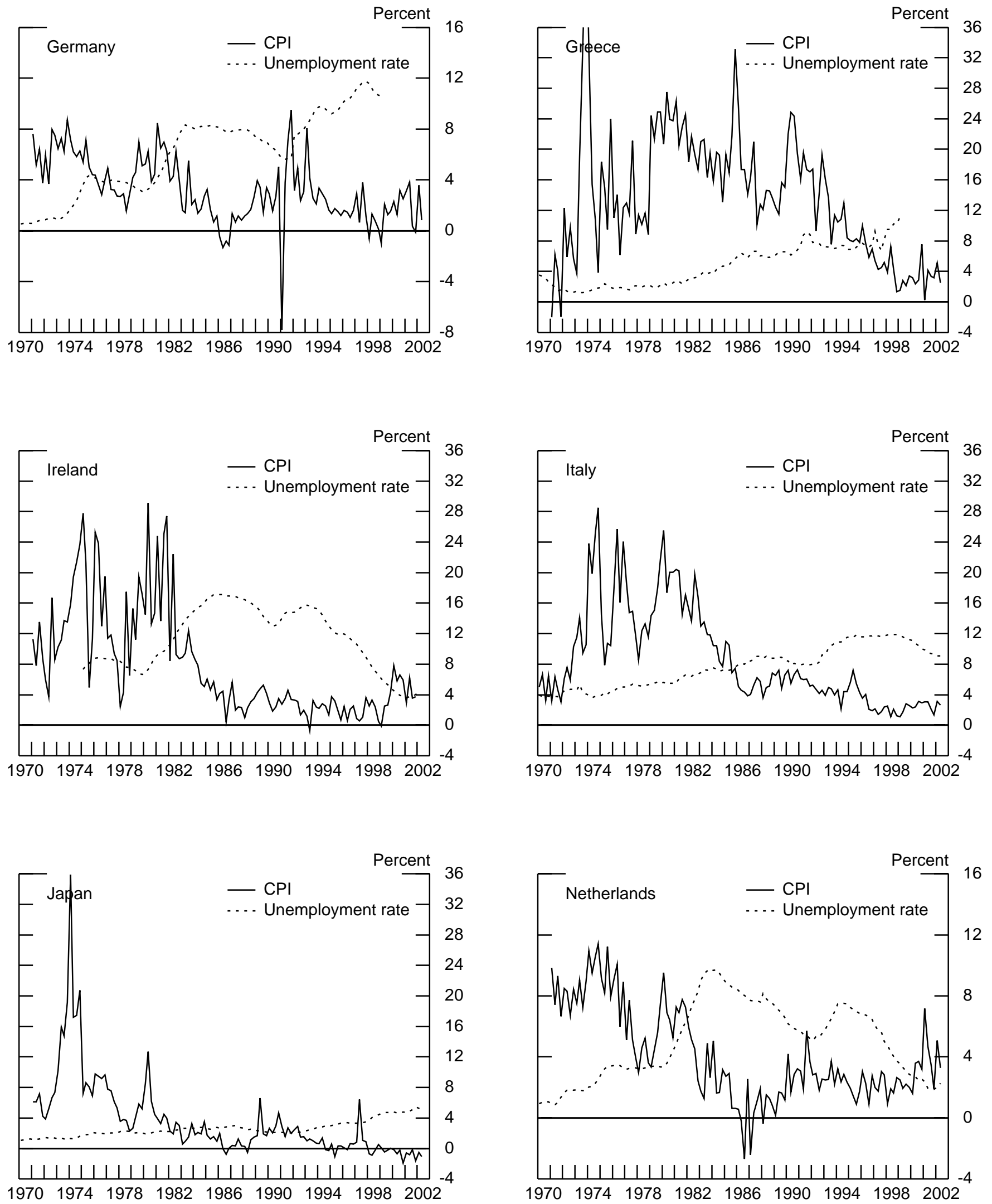

Inflation rates are quarterly (a.r.) growth rates of headline CPIs. Unemployment rates are quarterly averages. 
Figure 1

\section{Inflation and Unemployment Rates in Selected OECD Countries (continued)}
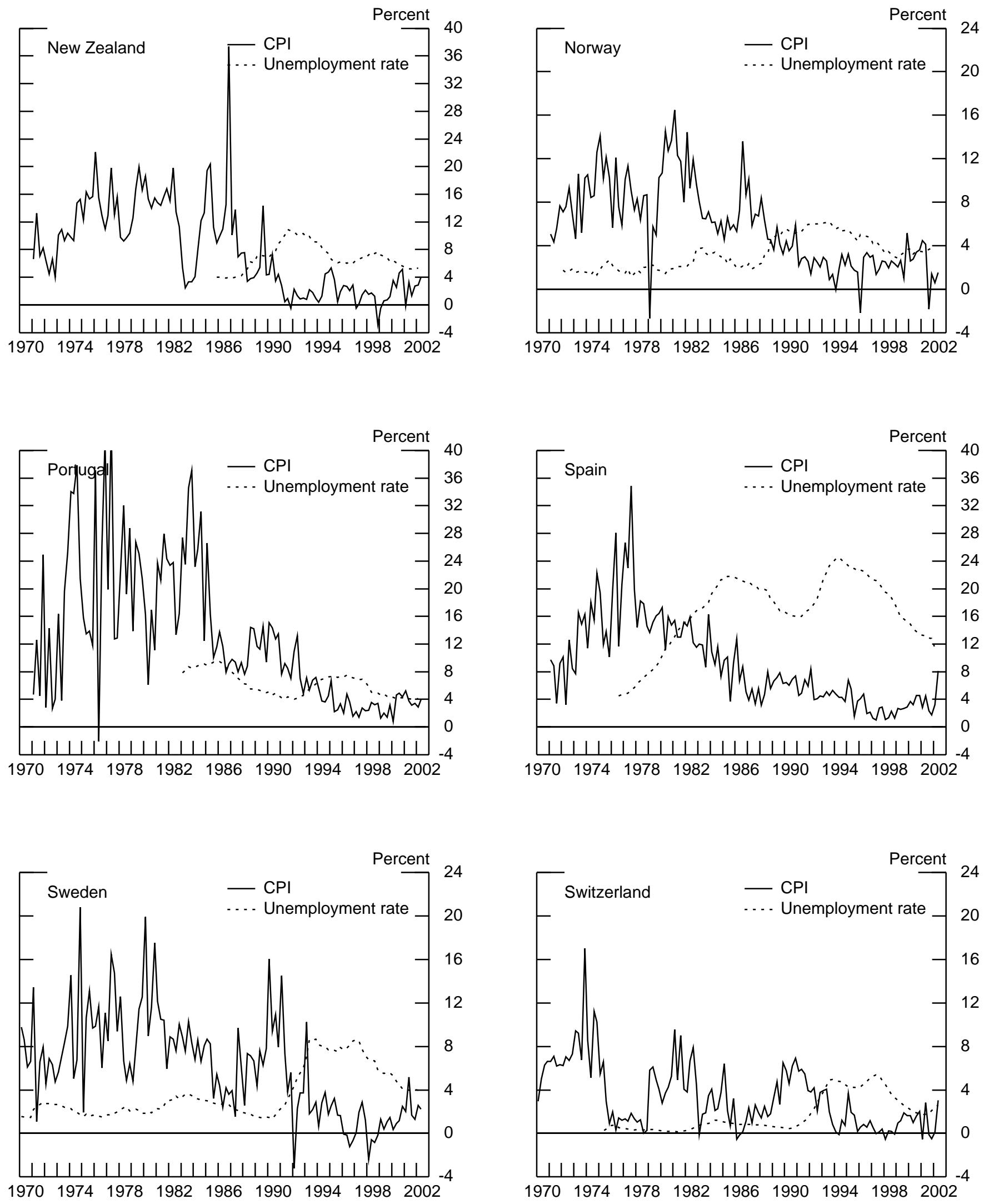

Inflation rates are quarterly (a.r.) growth rates of headline CPIs. Unemployment rates are quarterly averages. 
Figure 1

\section{Inflation and Unemployment Rates in Selected OECD Countries (continued)}

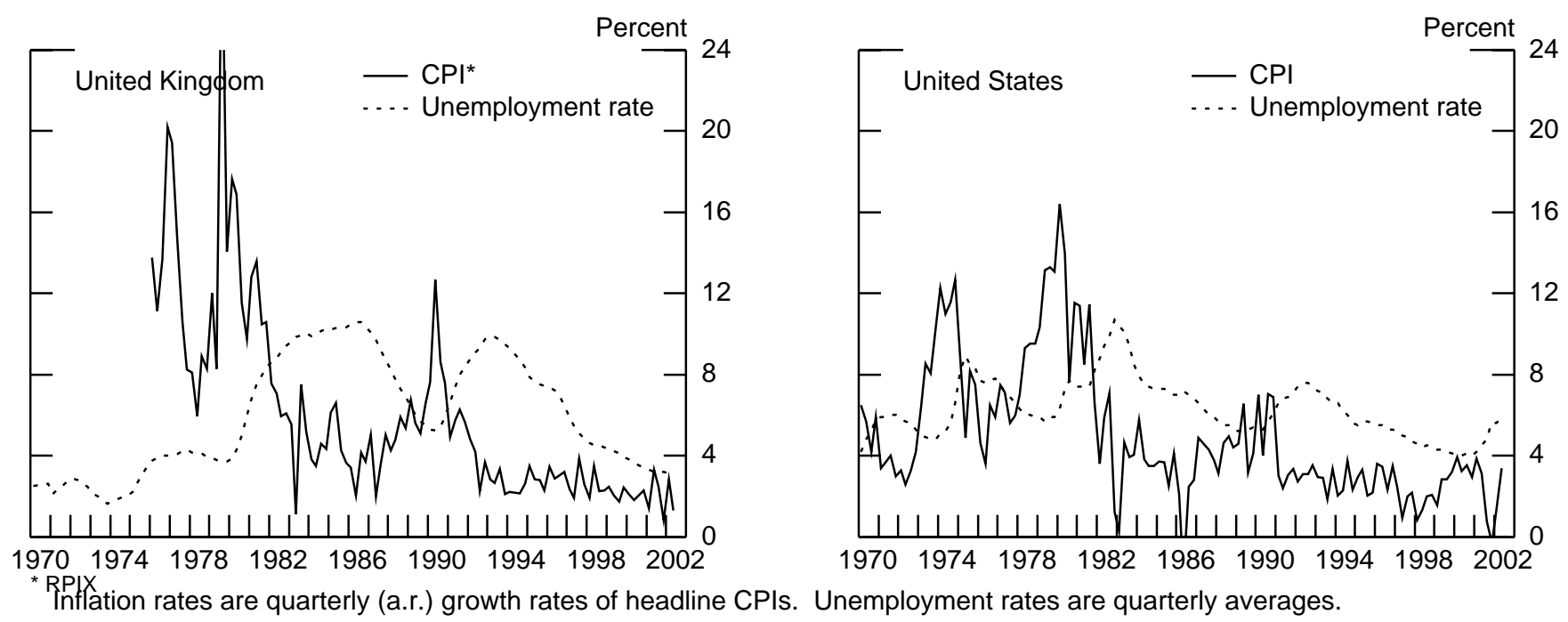


Figure 2

\section{Labor Market Developments}

United States

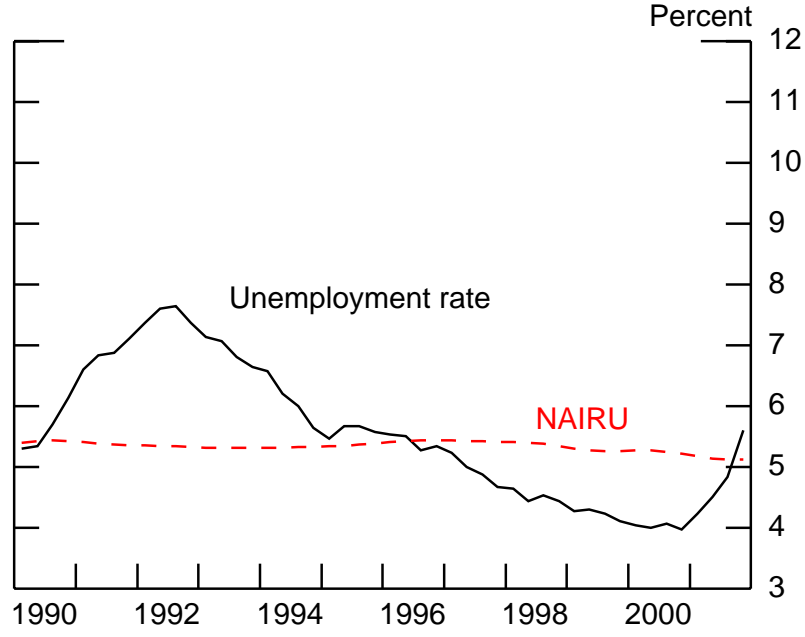

Source: NAIRU: OECD; unemployment rate: BLS.

\section{Euro Area}

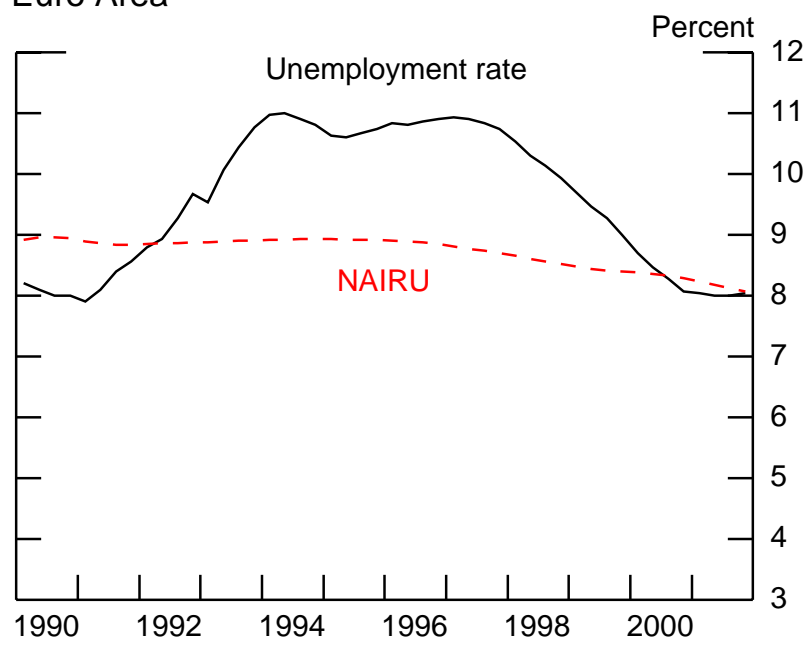

Source: NAIRU: OECD; unemployment rate: Eurostat.
Foreign Industrial Countries

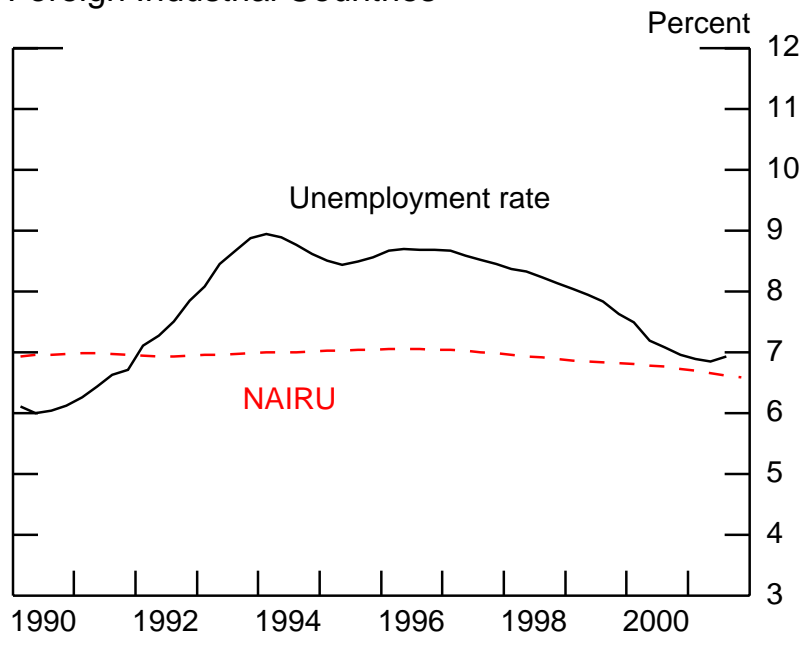

Source: Staff calculations using OECD data, GDP-weighted average across 19 foreign OECD countries.

United Kingdom

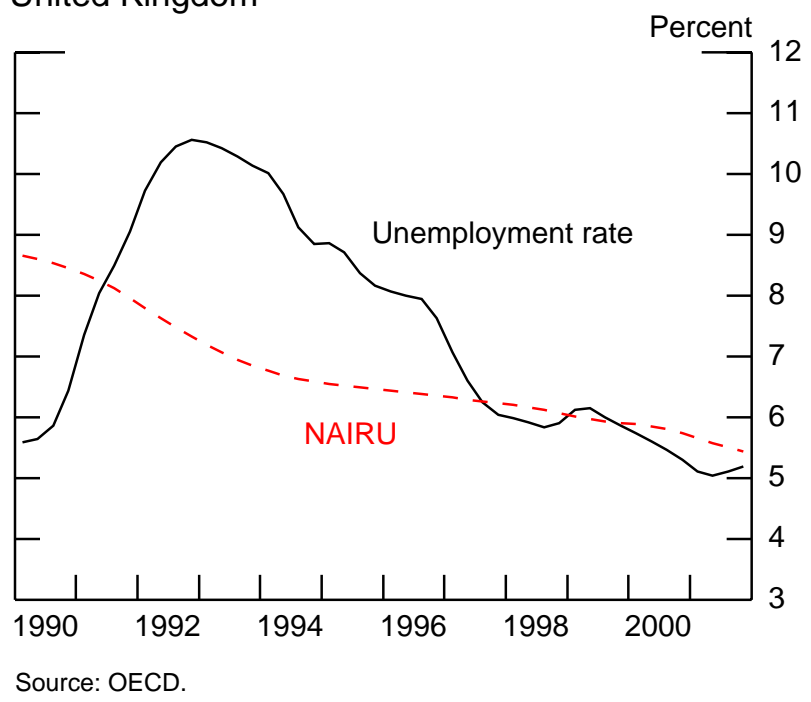




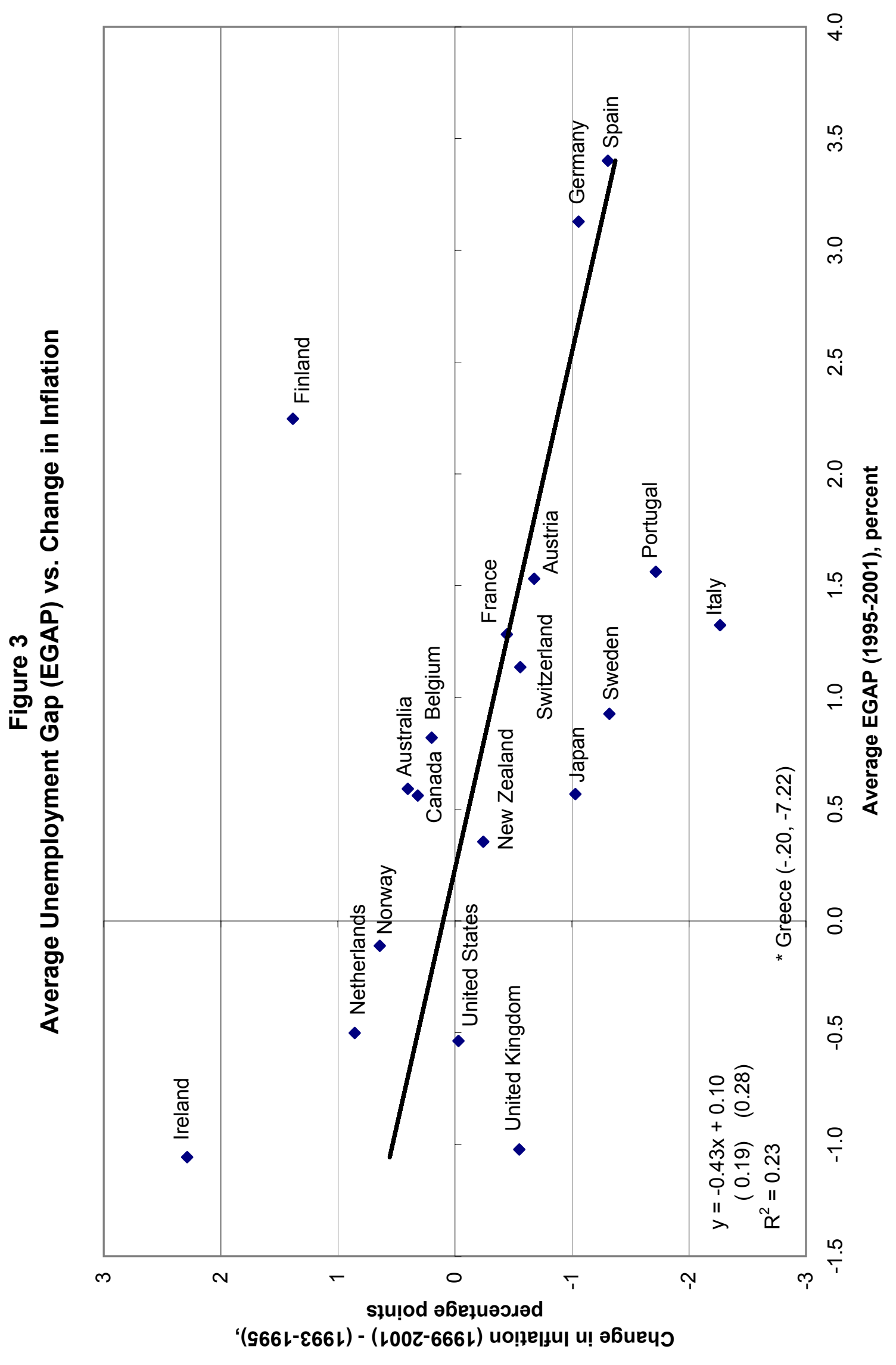




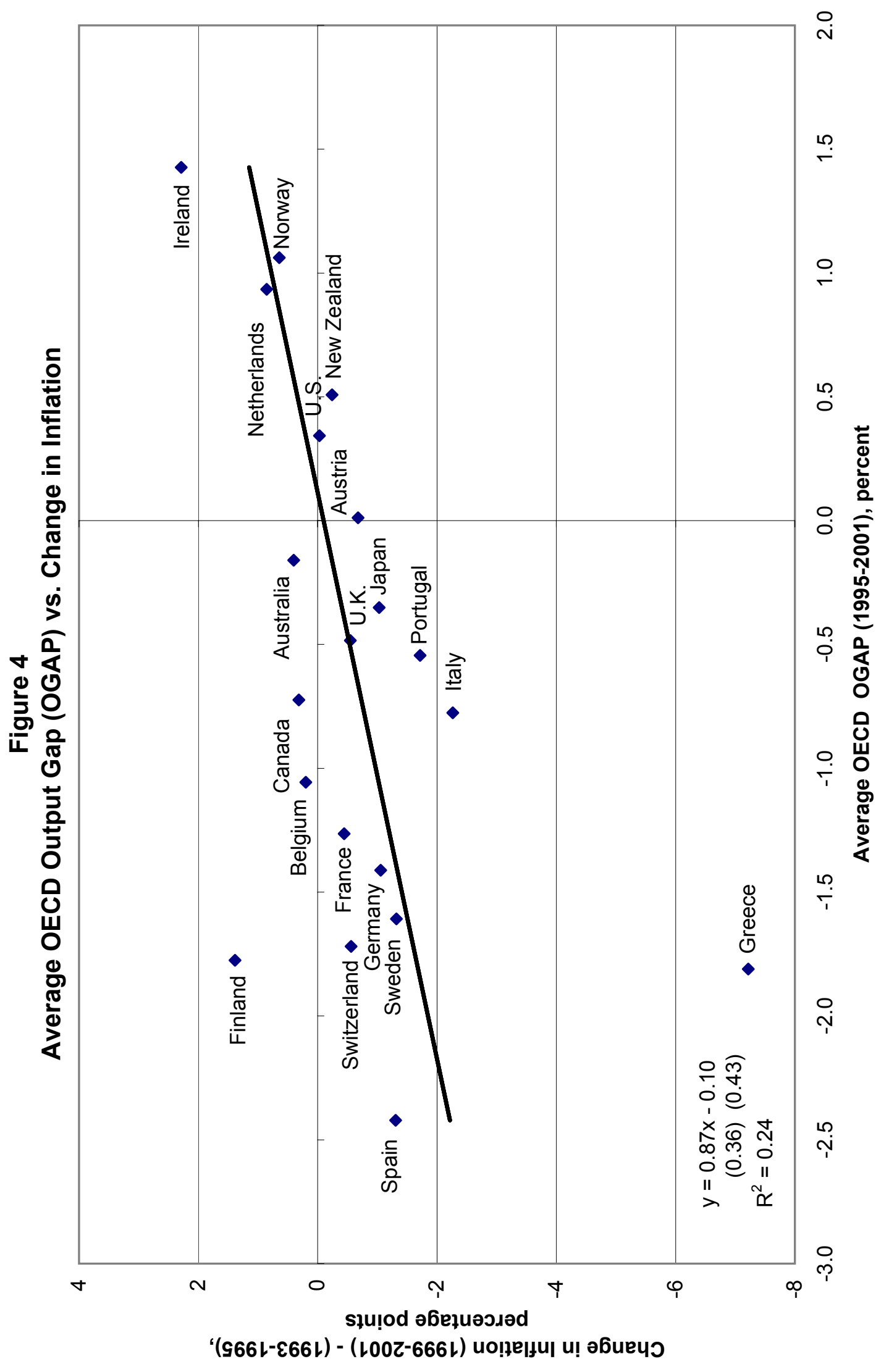




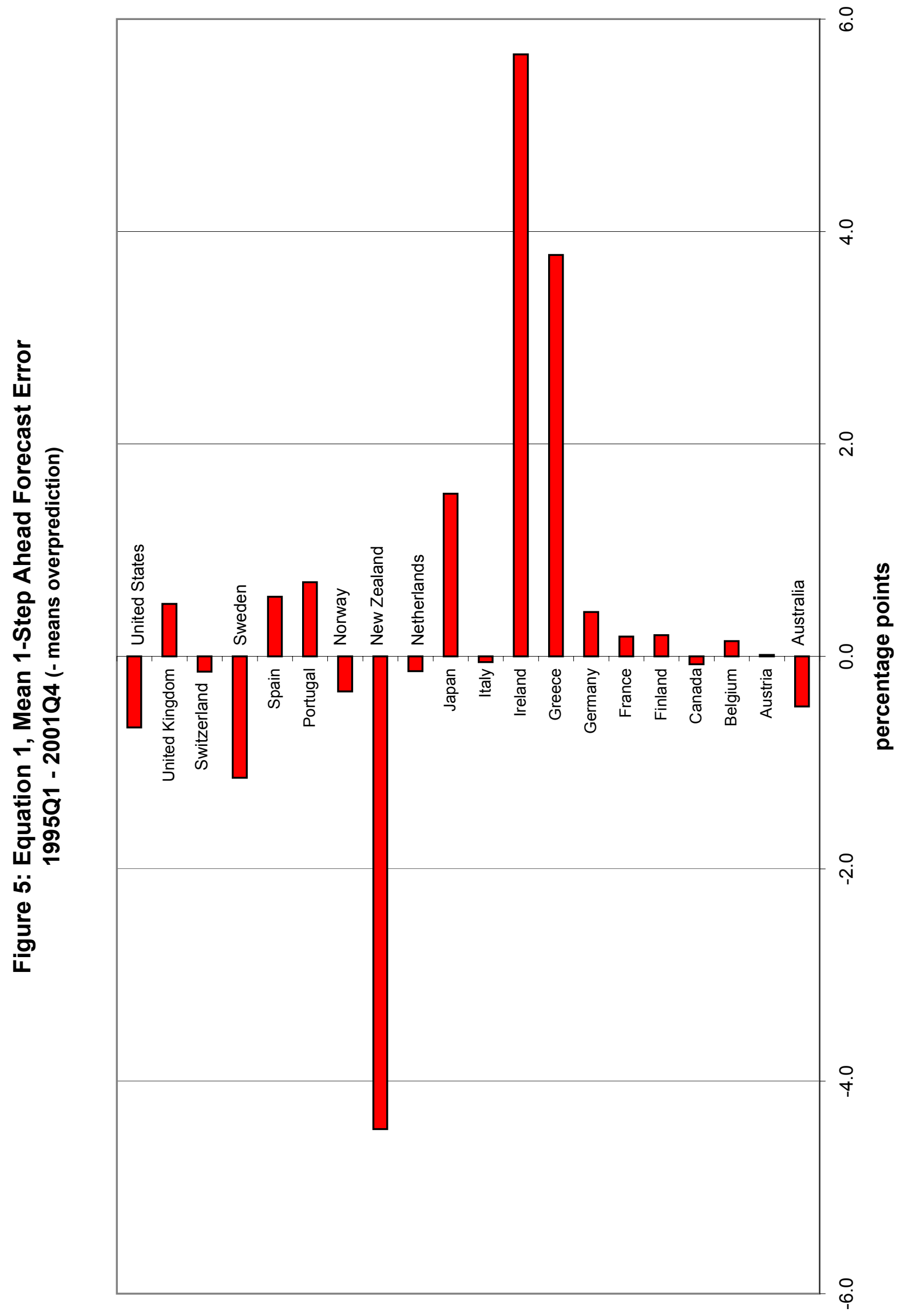




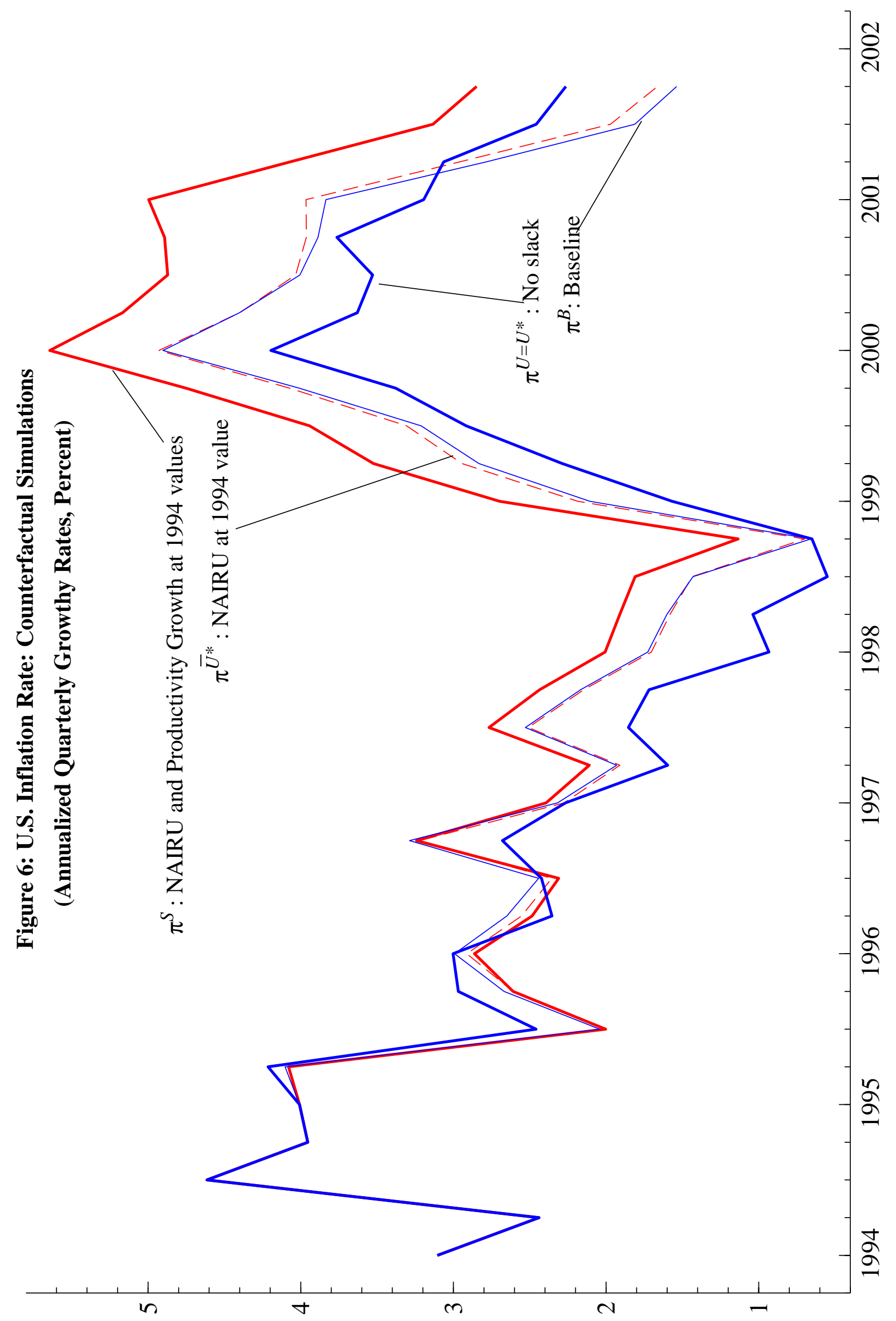




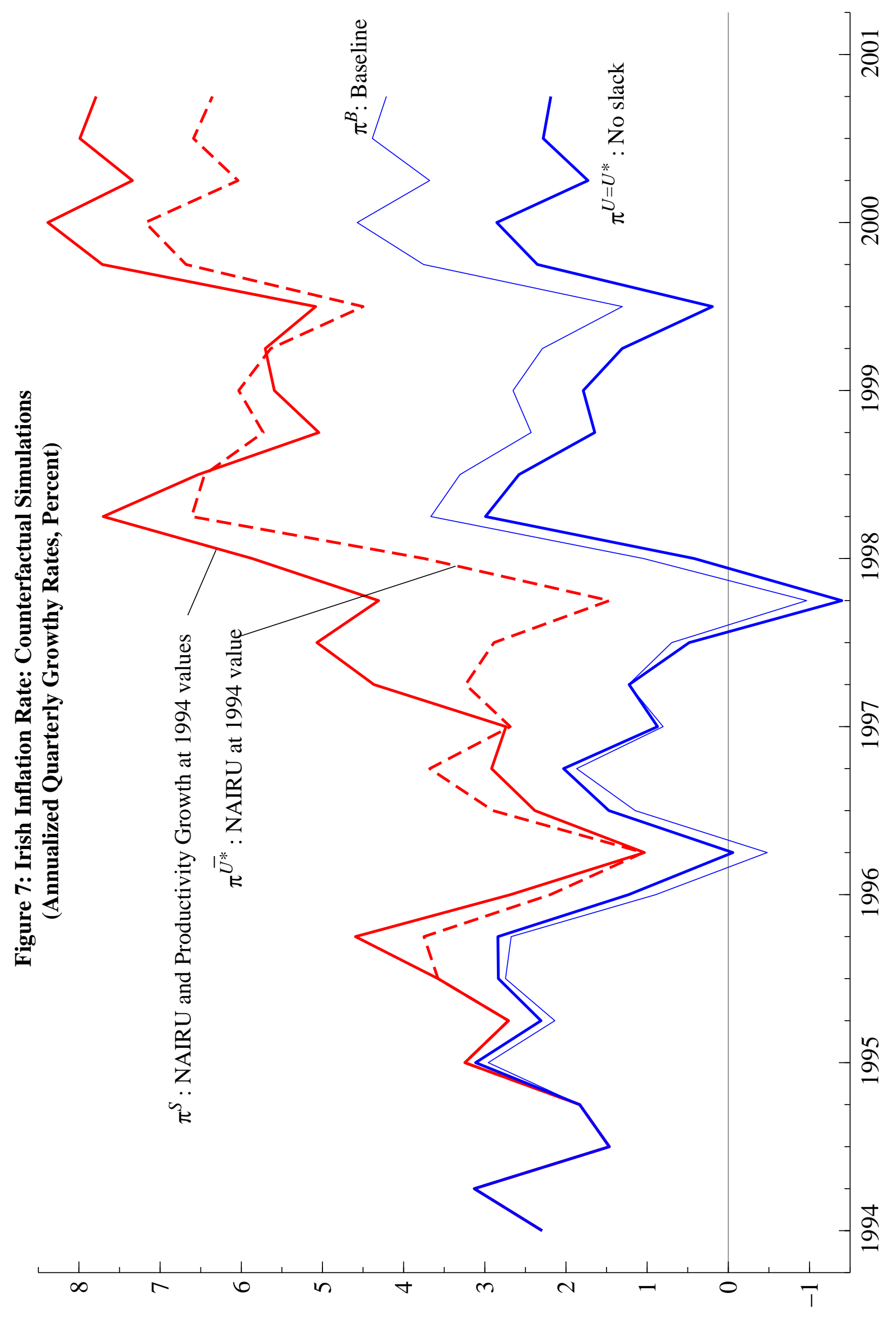




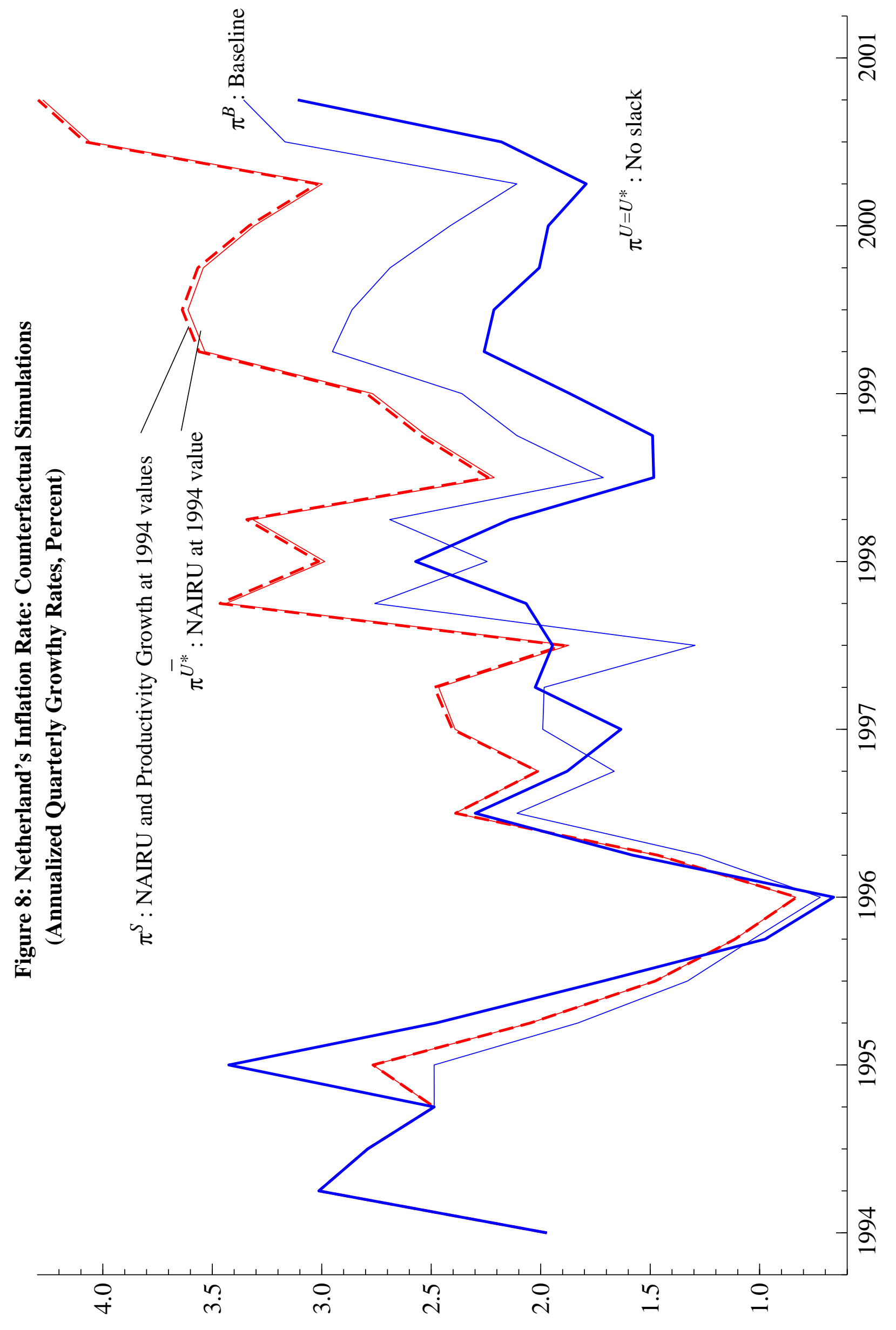




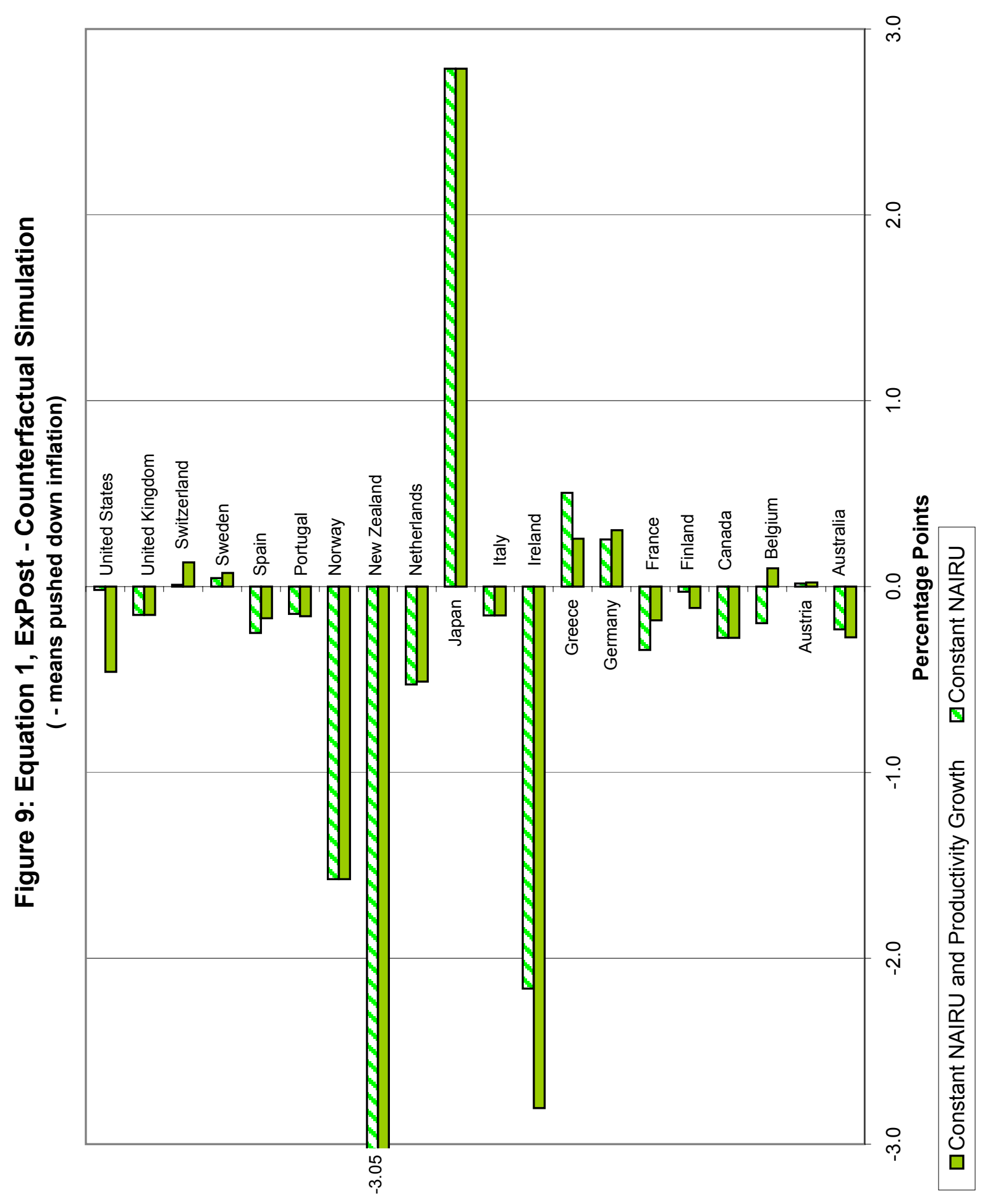


Figure A1

Unit Labor Costs in Selected OECD Countries
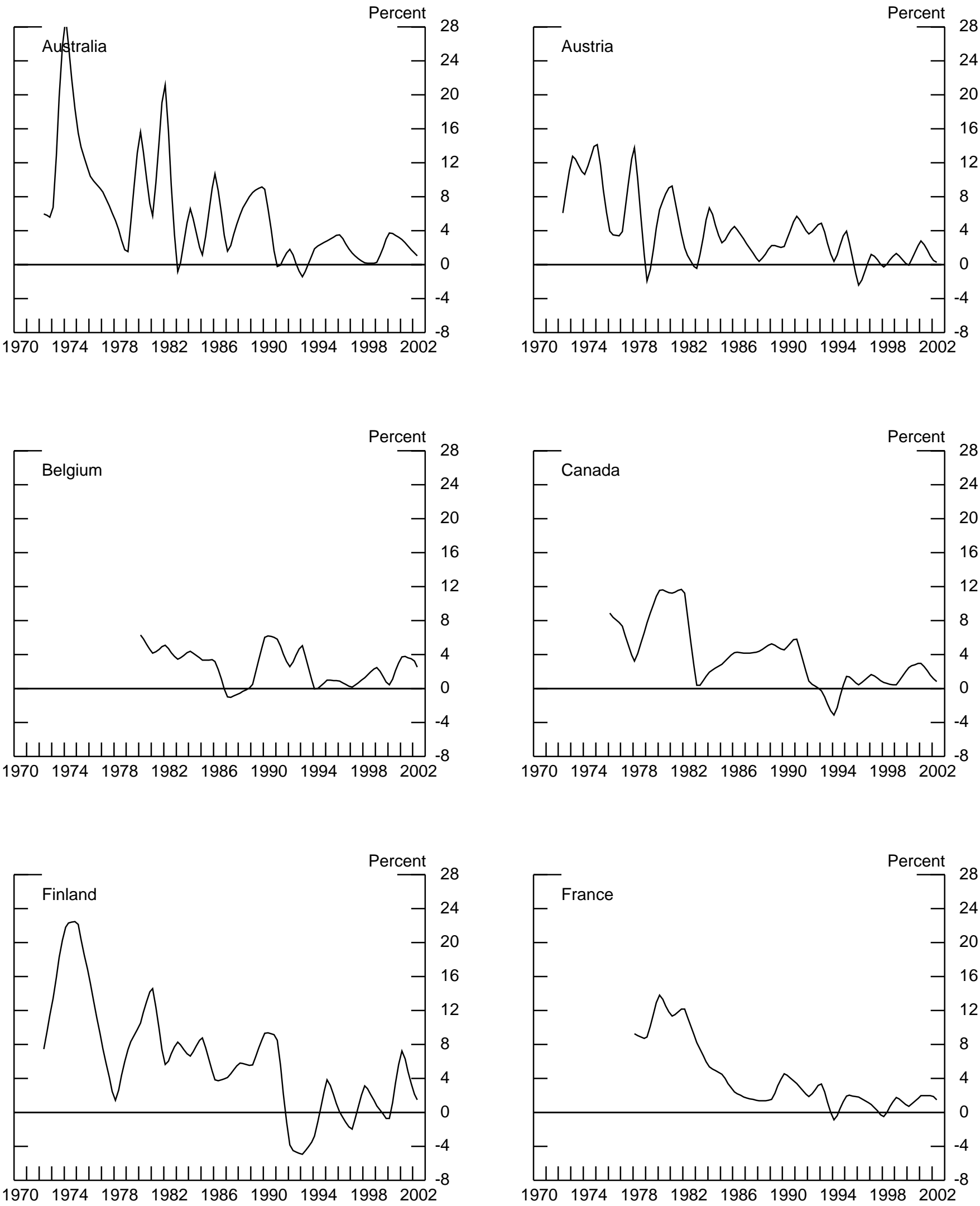

Unit labor costs are quarterly (ar.) growth rates. 
Figure A1

Unit Labor Costs in Selected OECD Countries (continued)
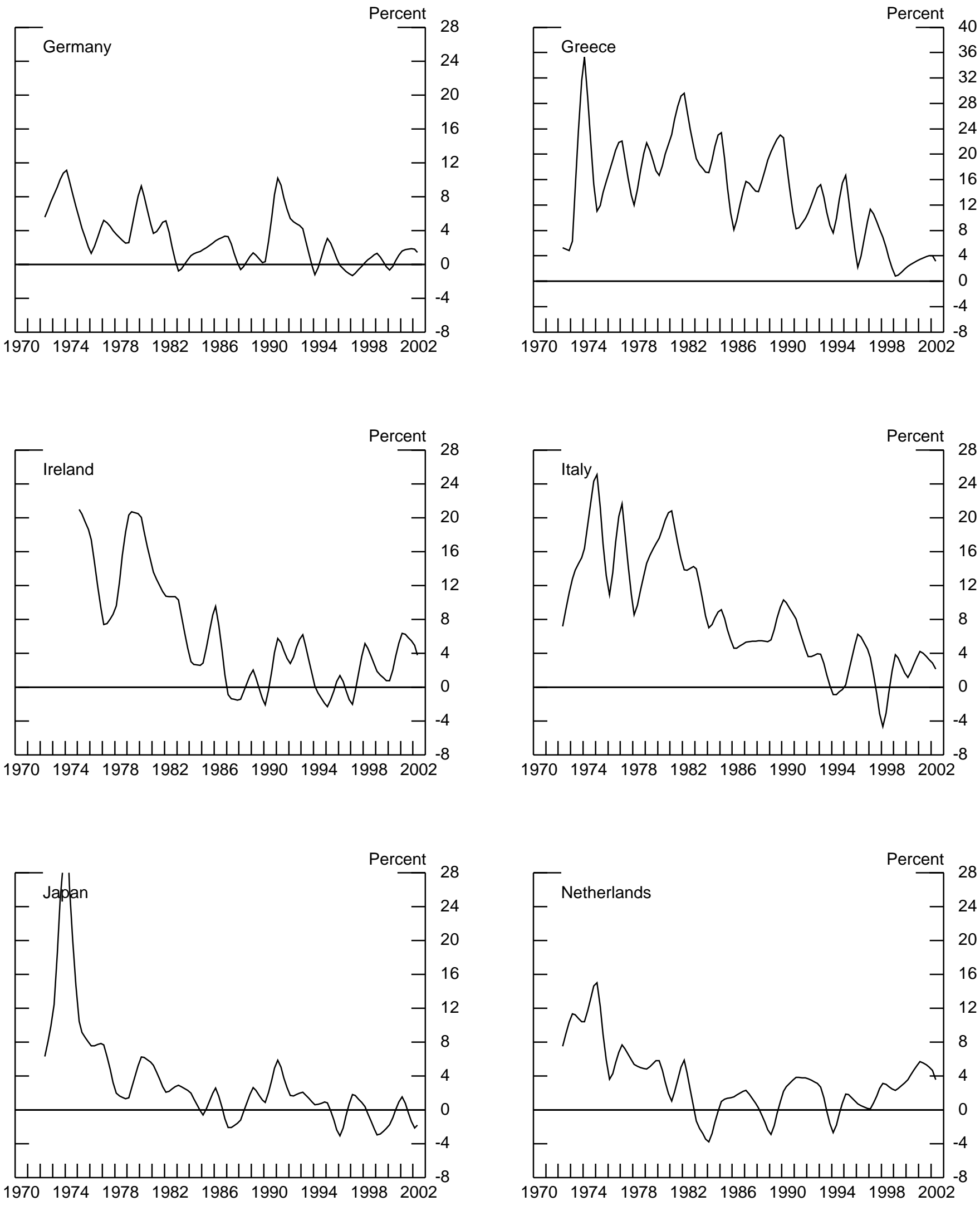

Unit labor costs are quarterly (ar.) growth rates. 
Figure A1

Unit Labor Costs in Selected OECD Countries (continued)
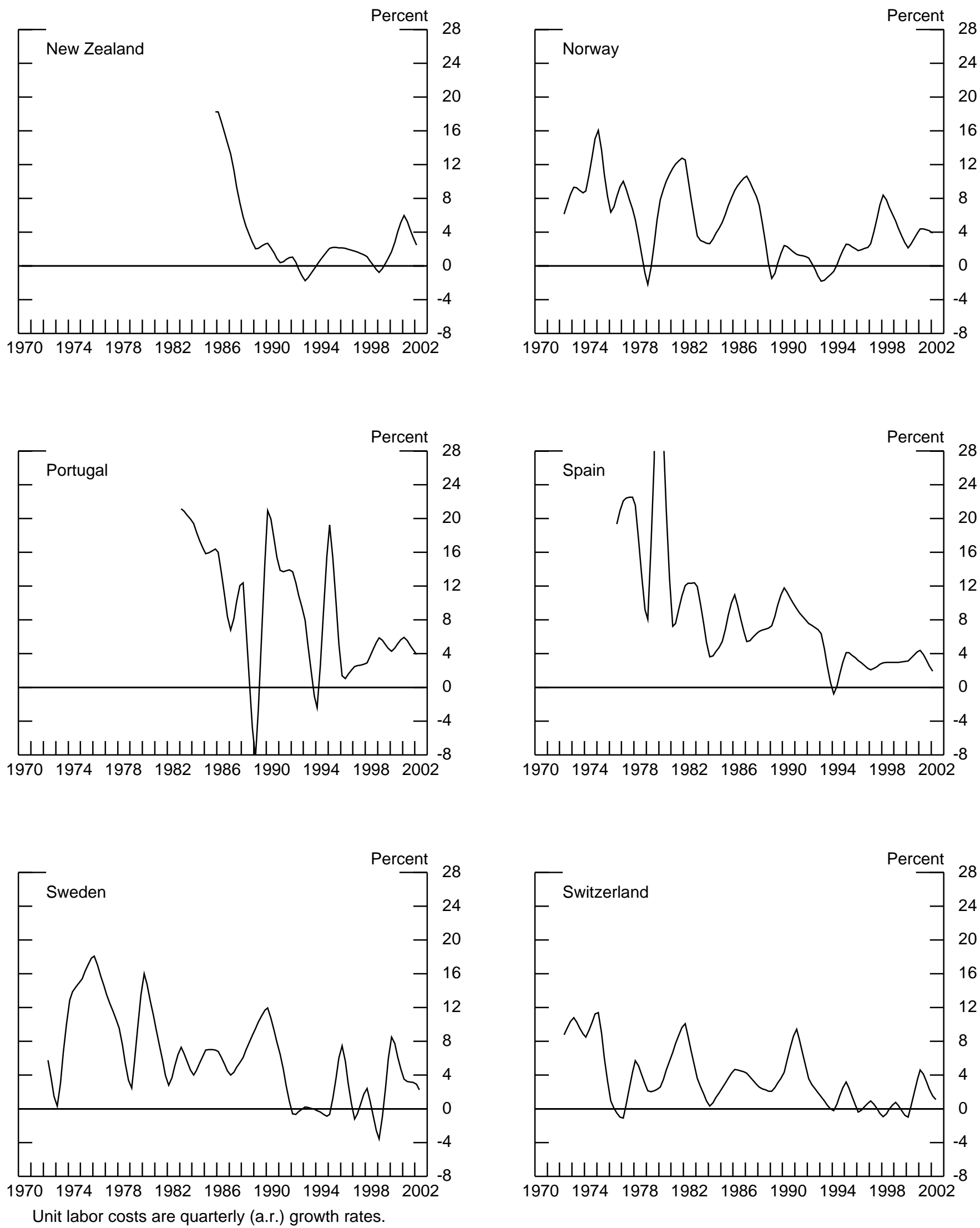
Figure A1

Unit Labor Costs in Selected OECD Countries (continued)
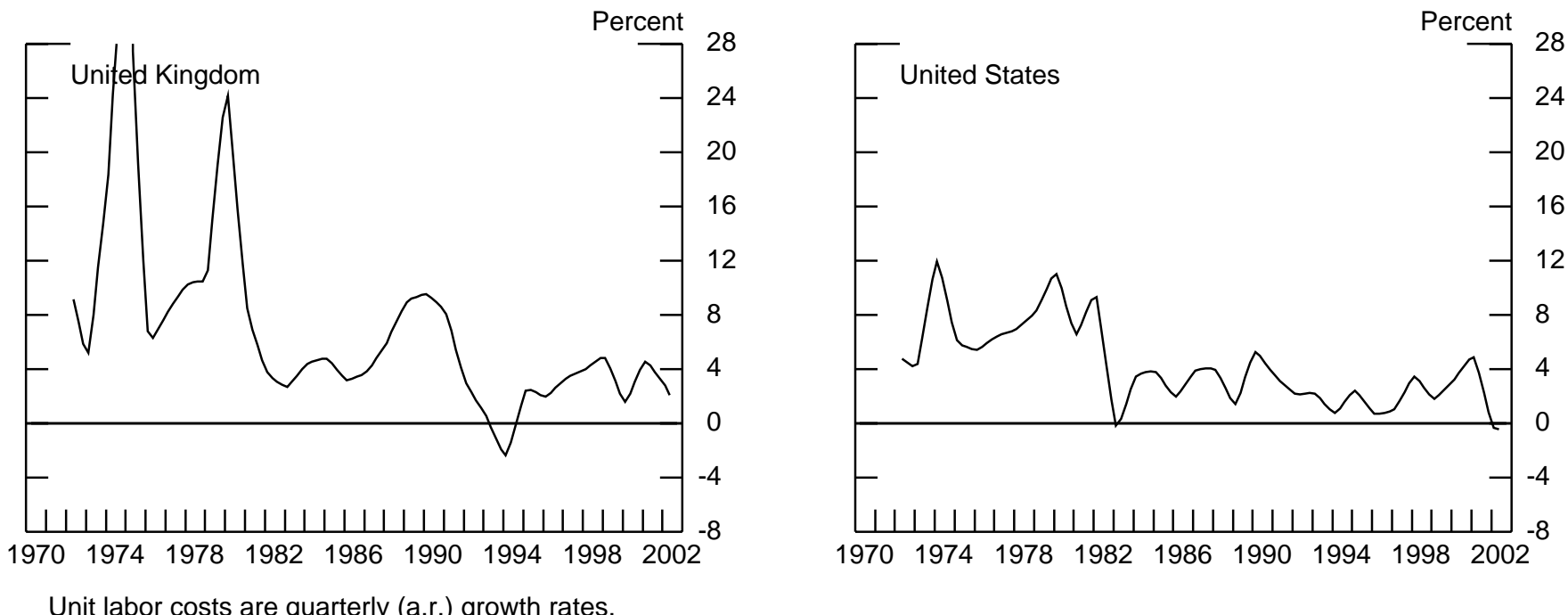

Unit labor costs are quarterly (ar.) growth rates. 
Figure A2 - Post-Pre Unemployment Coefficient, equation 3 2nd-1st sample

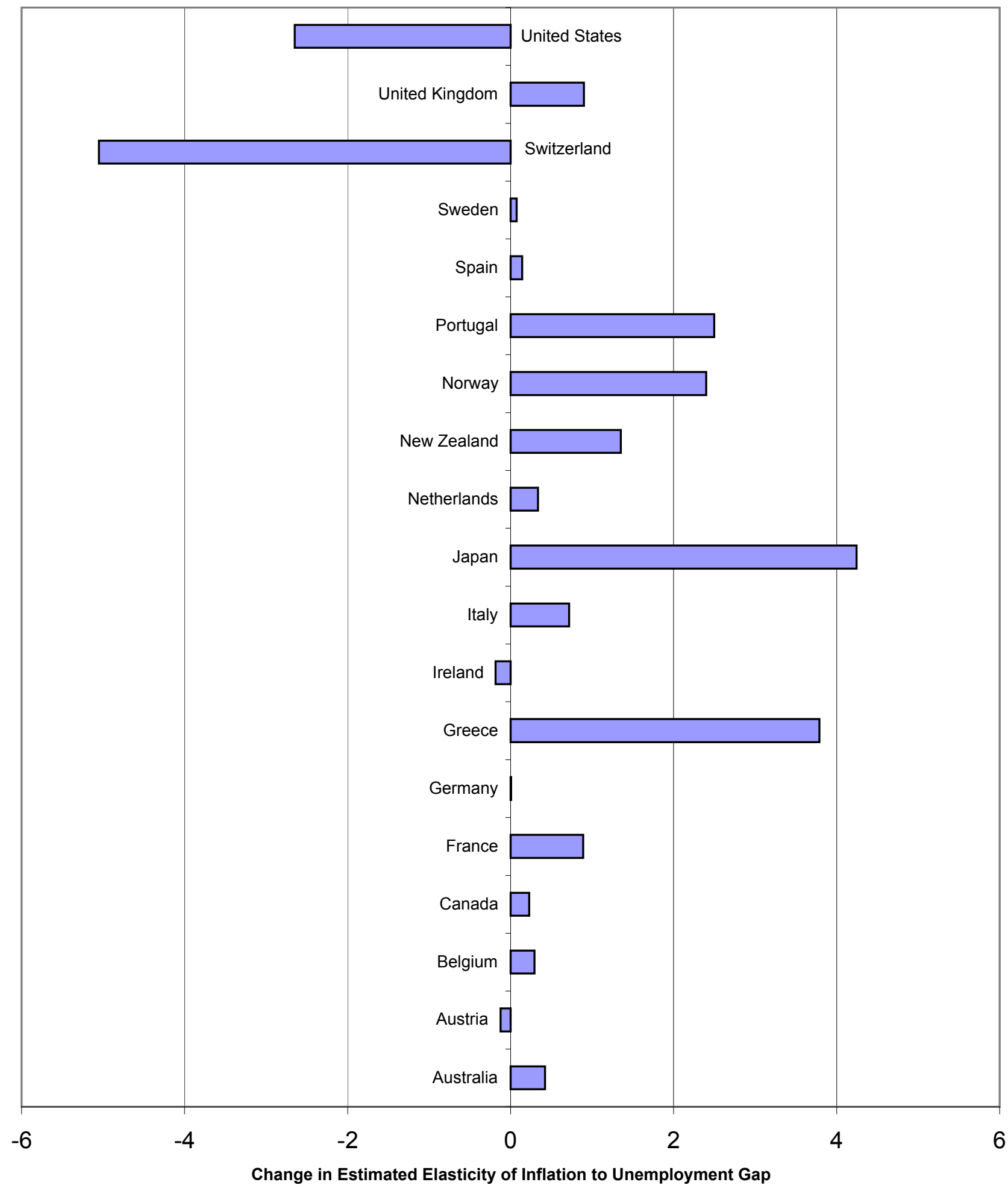




\section{Table 1}

Headline Inflation in Industrial Countries: Selected Periods Average of quarterly inflation (a.r.), percent

\begin{tabular}{|c|c|c|c|}
\hline Country & $1990-1994$ & $1995-2001$ & Change \\
\hline Australia & 2.64 & 2.66 & 0.02 \\
\hline Austria & 3.41 & 1.64 & -1.77 \\
\hline Belgium & 2.70 & 1.79 & -0.92 \\
\hline Canada & 2.52 & 1.80 & -0.72 \\
\hline Finland & 2.85 & 1.58 & -1.27 \\
\hline France & 2.42 & 1.34 & -1.08 \\
\hline Germany & 3.27 & 1.49 & -1.78 \\
\hline Greece & 15.61 & 4.83 & -10.78 \\
\hline Ireland & 2.47 & 2.99 & 0.52 \\
\hline Italy & 5.09 & 2.76 & -2.33 \\
\hline Japan & 1.77 & 0.09 & -1.68 \\
\hline Netherlands & 2.91 & 2.49 & -0.41 \\
\hline New Zealand & 2.27 & 1.86 & -0.42 \\
\hline Norway & 2.60 & 2.33 & -0.27 \\
\hline Portugal & 8.40 & 3.09 & -5.32 \\
\hline Spain & 5.32 & 2.96 & -2.36 \\
\hline Sweden & 5.41 & 1.02 & -4.39 \\
\hline Switzerland & 3.56 & 0.90 & -2.66 \\
\hline United Kingdom & 4.71 & 2.49 & -2.22 \\
\hline United States & 3.53 & 2.45 & -1.08 \\
\hline \multicolumn{4}{|l|}{ memos: } \\
\hline Foreign Median & 2.91 & 1.86 & -1.05 \\
\hline
\end{tabular}

Source: Headline CPI measures, except United Kingdom which is RPIX, from national statistic offices. 
Table 2

Unemployment Rates in Industrial Countries: Selected Periods

Averages at annual rates, percent

\begin{tabular}{lccccc}
\multicolumn{1}{c}{ Country } & $1990-1994$ & $1995-2001$ & $\begin{array}{c}\text { Change } \\
(90-94) \text { to (95-01) }\end{array}$ & $1999-2001$ & $\begin{array}{c}\text { Change } \\
\text { (90-94) to (99-01) }\end{array}$ \\
\hline \hline Australia & 9.30 & 7.49 & -1.81 & 6.66 & -2.65 \\
Austria & 6.11 & 6.65 & 0.54 & 6.19 & 0.09 \\
Belgium & 7.70 & 8.55 & 0.85 & 7.35 & -0.34 \\
Canada & 10.27 & 8.29 & -1.98 & 7.20 & -3.08 \\
Finland & 10.95 & 11.84 & 0.89 & 9.71 & -1.24 \\
France & 10.44 & 11.04 & 0.60 & 9.84 & -0.60 \\
Germany & 7.66 & 10.27 & 2.61 & 9.83 & 2.17 \\
Greece & 7.39 & 9.37 & 1.97 & 11.07 & 3.67 \\
Ireland & 14.50 & 7.73 & -6.77 & 4.44 & -10.06 \\
Italy & 9.11 & 11.20 & 2.09 & 10.51 & 1.40 \\
Japan & 2.35 & 4.07 & 1.72 & 4.82 & 2.47 \\
Netherlands & 6.11 & 4.48 & -1.63 & 2.61 & -3.50 \\
New Zealand & 9.20 & 6.38 & -2.82 & 6.04 & -3.16 \\
Norway & 5.70 & 3.92 & -1.78 & 3.43 & -2.27 \\
Portugal & 5.19 & 5.62 & 0.44 & 4.26 & -0.93 \\
Spain & 19.57 & 18.26 & -1.31 & 14.33 & -5.24 \\
Sweden & 5.21 & 6.36 & 1.14 & 4.74 & -0.47 \\
Switzerland & 2.68 & 3.50 & 0.82 & 2.18 & -0.49 \\
United Kingdom & 8.82 & 6.50 & -2.32 & 5.56 & -3.27 \\
United States & 6.60 & 4.78 & -1.81 & 4.34 & -2.25 \\
& & & & & -1.50 \\
\hline Foreign Median & 7.70 & 7.49 & -0.21 & 6.19 & \\
& & & & &
\end{tabular}

Source: Unemployment rates are from national statistic offices. 


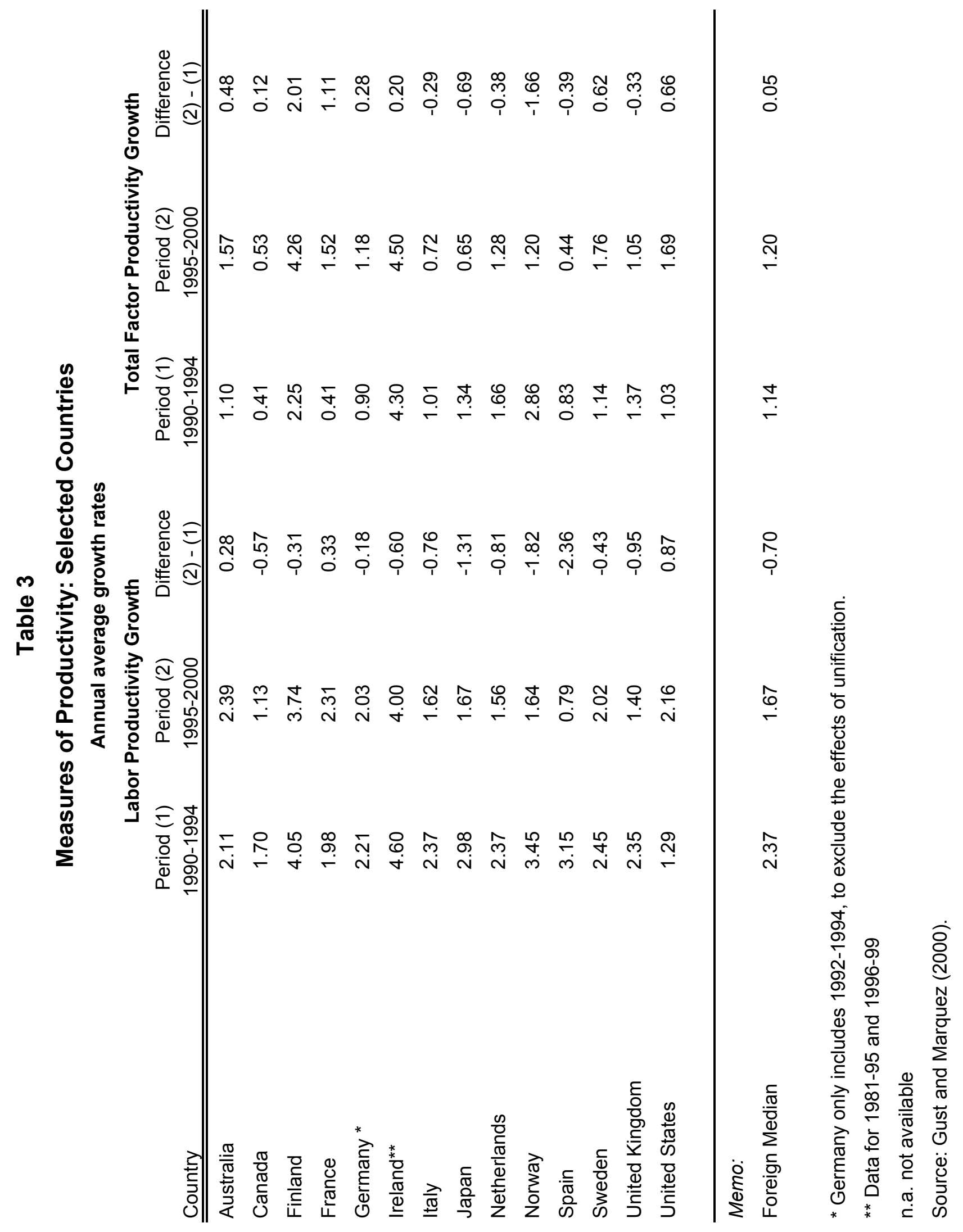


Table 4

\section{Credibility of Monetary Policy: Selected Periods}

Taylor Rule Inflation Coefficient*

\begin{tabular}{|c|c|c|c|}
\hline Country & 1st period & 2nd period & Date of Sample Break \\
\hline Australia & 0.74 & -3.28 & 1993 \\
\hline Austria & 0.47 & 2.03 & 1984 \\
\hline Belgium & -1.10 & 2.40 & 1986 \\
\hline Canada & 0.50 & 1.43 & 1984 \\
\hline Finland & -0.66 & 2.90 & 1984 \\
\hline France & 0.69 & 2.92 & 1986 \\
\hline Germany & 3.52 & 1.82 & 1980 \\
\hline Greece & 0.34 & 0.29 & 1993 \\
\hline Ireland & 0.36 & 2.51 & 1984 \\
\hline Italy & 1.05 & 2.50 & 1986 \\
\hline Japan & 2.78 & 2.46 & 1980 \\
\hline Netherlands & 0.22 & -4.77 & 1984 \\
\hline New Zealand & -0.37 & 5.66 & 1990 \\
\hline Norway & -0.86 & 7.14 & 1989 \\
\hline Portugal & 1.01 & 1.77 & 1986 \\
\hline Spain & 0.28 & 3.00 & 1986 \\
\hline Sweden & -0.52 & -1.28 & 1992 \\
\hline Switzerland & 0.36 & 1.09 & 1984 \\
\hline United Kingdom & 0.56 & 1.51 & 1980 \\
\hline United States & 0.70 & 1.22 & 1980 \\
\hline Foreign Median & 0.36 & 2.03 & \\
\hline
\end{tabular}

\footnotetext{
* Taylor Rule inflation coefficients are from Gagnon and Ihrig (2001).
} 
Table 5: OLS Coefficient Estimates and Residual Properties

Sensitivity to Measures of Slack

(standard errors in parentheses)

\begin{tabular}{|c|c|c|c|c|c|c|c|c|}
\hline \multirow[t]{3}{*}{$\begin{array}{l}\text { Dependent Variable is } \\
\text { Headline Inflation Rate (s.a.) }\end{array}$} & \multicolumn{4}{|c|}{ Australia } & \multicolumn{4}{|c|}{ Austria } \\
\hline & \multicolumn{2}{|c|}{ Potential Output } & \multicolumn{2}{|c|}{$\begin{array}{l}\text { Natural Rate of } \\
\text { Unemployment }\end{array}$} & \multicolumn{2}{|c|}{ Potential Output } & \multicolumn{2}{|c|}{$\begin{array}{l}\text { Natural Rate of } \\
\text { Unemployment }\end{array}$} \\
\hline & $\begin{array}{l}\text { Moving } \\
\text { Average }\end{array}$ & $\begin{array}{l}\text { HP } \\
\text { Filter }\end{array}$ & $\begin{array}{l}\text { HP } \\
\text { Filter }\end{array}$ & OECD & $\begin{array}{l}\text { Moving } \\
\text { Average }\end{array}$ & $\begin{array}{l}\text { HP } \\
\text { Filter }\end{array}$ & $\begin{array}{l}\text { HP } \\
\text { Filter }\end{array}$ & OECD \\
\hline$\left(\mathrm{Y}-\mathrm{Y}^{*}\right) / \mathrm{Y}^{*}$ & $\begin{array}{c}0.63 \\
(0.21)\end{array}$ & $\begin{array}{c}0.58 \\
(0.26)\end{array}$ & -- & -- & $\begin{array}{c}0.33 \\
(0.10)\end{array}$ & $\begin{array}{c}0.32 \\
(0.15)\end{array}$ & -- & -- \\
\hline $\mathrm{U}-\mathrm{U}^{*}$ & -- & -- & $\begin{array}{l}+0.06 \\
(0.33)\end{array}$ & $\begin{array}{l}-0.14 \\
(0.24)\end{array}$ & -- & -- & $\begin{array}{l}-0.98 \\
(0.50)\end{array}$ & $\begin{array}{l}-0.68 \\
(0.34)\end{array}$ \\
\hline$[\log (\mathrm{CPI})-\log ($ Mprice $)]$ & -- & -- & -- & -- & -- & -- & -- & -- \\
\hline$[\log (\mathrm{CPI})-\log (\mathrm{ULC})]$ & $\begin{array}{l}-0.02 \\
(0.05)\end{array}$ & $\begin{array}{c}-0.02 \\
(0.05)\end{array}$ & $\begin{array}{l}+0.01 \\
(0.05)\end{array}$ & $\begin{array}{l}-0.01 \\
(0.05)\end{array}$ & $\begin{array}{l}-0.20 \\
(0.08)\end{array}$ & $\begin{array}{l}-0.03 \\
(0.07)\end{array}$ & $\begin{array}{l}+0.03 \\
(0.05)\end{array}$ & $\begin{array}{c}-0.002 \\
(0.05)\end{array}$ \\
\hline $\mathrm{R}^{2}$ & 0.47 & 0.39 & 0.44 & 0.46 & 0.52 & 0.30 & 0.36 & 0.38 \\
\hline SER ( $\%$ a.r.) & 3.40 & 3.56 & 3.39 & 3.34 & 1.43 & 1.73 & 1.67 & 1.65 \\
\hline Residual Properties (p-values) & & & & & & & & \\
\hline Serial Independence & 0.86 & 0.80 & 0.68 & 0.63 & 0.26 & 0.65 & 0.45 & 0.51 \\
\hline Homoskedasticity & 0.03 & 0.00 & 0.00 & 0.01 & 0.73 & 0.99 & 0.99 & 0.99 \\
\hline Normality & 0.00 & 0.00 & 0.09 & 0.13 & 0.15 & 0.00 & 0.00 & 0.01 \\
\hline Sample & 74-94 & 72-94 & $72-94$ & $72-94$ & 74-94 & $72-94$ & $72-94$ & $72-94$ \\
\hline
\end{tabular}

${ }^{a}$ Entries correspond to the significance level to reject the associated hypothesis; an entry of 0.05 means that one can reject the hypothesis with a 5 percent significance level. Serial Independence: F-test for the hypothesis that all of the coefficients of an AR(5) for the residuals are equal to zero. Homoskedasticity: ARCH t-test. Normality: Jarque-Bera chi-squared test.

Y: Real GDP

$\mathrm{Y}^{*}$ : Potential GDP

$\mathrm{U}$ : Unemployment rate

U*: Natural Rate of Unemployment

CPI: Level of headline CPI

ULC: Level of unit-labor cost

Mprice: Level of import prices

Moving averages use contemporaneous and lags of 12 quarters GDP. 
Table 5: OLS Coefficient Estimates and Residual Properties

Sensitivity to Measures of Slack

(standard errors in parentheses)

\begin{tabular}{|c|c|c|c|c|c|c|c|c|}
\hline \multirow[t]{3}{*}{$\begin{array}{l}\text { Dependent Variable is } \\
\text { Headline Inflation Rate (s.a.) }\end{array}$} & \multicolumn{4}{|c|}{ Belgium } & \multicolumn{4}{|c|}{ Canada } \\
\hline & \multicolumn{2}{|c|}{ Potential Output } & \multicolumn{2}{|c|}{$\begin{array}{l}\text { Natural Rate of } \\
\text { Unemployment }\end{array}$} & \multicolumn{2}{|c|}{ Potential Output } & \multicolumn{2}{|c|}{$\begin{array}{l}\text { Natural Rate of } \\
\text { Unemployment }\end{array}$} \\
\hline & $\begin{array}{l}\text { Moving } \\
\text { Average }\end{array}$ & $\begin{array}{l}\text { HP } \\
\text { Filter }\end{array}$ & $\begin{array}{l}\text { HP } \\
\text { Filter }\end{array}$ & OECD & $\begin{array}{l}\text { Moving } \\
\text { Average }\end{array}$ & $\begin{array}{l}\text { HP } \\
\text { Filter }\end{array}$ & $\begin{array}{l}\text { HP } \\
\text { Filter }\end{array}$ & OECD \\
\hline$\left(\mathrm{Y}-\mathrm{Y}^{*}\right) / \mathrm{Y}^{*}$ & $\begin{array}{c}0.26 \\
(0.17)\end{array}$ & $\begin{array}{c}0.04 \\
(0.19)\end{array}$ & -- & -- & $\begin{array}{c}0.34 \\
(0.15)\end{array}$ & $\begin{array}{c}0.47 \\
(0.13)\end{array}$ & -- & -- \\
\hline $\mathrm{U}-\mathrm{U}^{*}$ & -- & -- & $\begin{array}{l}-0.27 \\
(0.21)\end{array}$ & $\begin{array}{l}-0.30 \\
(0.13)\end{array}$ & -- & -- & $\begin{array}{l}-0.29 \\
(0.19)\end{array}$ & $\begin{array}{l}-0.14 \\
(0.12)\end{array}$ \\
\hline$[\log (\mathrm{CPI})-\log ($ Mprice $)]$ & -- & $\begin{array}{l}+0.03 \\
(0.02)\end{array}$ & -- & -- & $\begin{array}{l}+0.04 \\
(0.03)\end{array}$ & $\begin{array}{l}-0.02 \\
(0.02)\end{array}$ & -- & $\begin{array}{l}-0.01 \\
(0.01)\end{array}$ \\
\hline$[\log (\mathrm{CPI})-\log (\mathrm{ULC})]$ & $\begin{array}{l}-0.12 \\
(0.08)\end{array}$ & -- & $\begin{array}{l}-0.05 \\
(0.05)\end{array}$ & $\begin{array}{l}-0.15 \\
(0.08)\end{array}$ & $\begin{array}{l}-0.10 \\
(0.13)\end{array}$ & $\begin{array}{l}+0.08 \\
(0.09)\end{array}$ & -- & -- \\
\hline $\mathrm{R}^{2}$ & 0.39 & 0.44 & 0.30 & 0.34 & 0.76 & 0.64 & 0.67 & 0.71 \\
\hline SER (\% a.r.) & 1.40 & 1.36 & 1.48 & 1.44 & 1.24 & 1.48 & 1.43 & 1.13 \\
\hline Residual Properties (p-values) & & & & & & & & \\
\hline Serial Independence & 0.63 & 0.95 & 0.28 & 0.09 & 0.48 & 0.90 & 0.56 & 0.17 \\
\hline Homoskedasticity & 0.56 & 0.99 & 0.68 & 0.25 & 0.59 & 0.33 & 0.73 & 0.45 \\
\hline Normality & 0.31 & 0.46 & 0.35 & 0.47 & 0.51 & 0.80 & 0.35 & 0.99 \\
\hline Sample & $81-94$ & $81-94$ & $81-94$ & $81-94$ & $81-94$ & $81-94$ & $81-94$ & $77-94$ \\
\hline
\end{tabular}

${ }^{a}$ Entries correspond to the significance level to reject the associated hypothesis; an entry of 0.05 means that one can reject the hypothesis with a 5 percent significance level. Serial Independence: F-test for the hypothesis that all of the coefficients of an AR(5) for the residuals are equal to zero. Homoskedasticity: ARCH t-test. Normality: Jarque-Bera chi-squared test.

Y: Real GDP

$\mathrm{Y}^{*}$ : Potential GDP

$\mathrm{U}$ : Unemployment rate

U*: Natural Rate of Unemployment

CPI: Level of headline CPI

ULC: Level of unit-labor cost

Mprice: Level of import prices

Moving averages use contemporaneous and lags of 12 quarters GDP. 
Table 5: OLS Coefficient Estimates and Residual Properties

Sensitivity to Measures of Slack

(standard errors in parentheses)

\begin{tabular}{|c|c|c|c|c|c|c|c|c|}
\hline \multirow[t]{3}{*}{$\begin{array}{l}\text { Dependent Variable is } \\
\text { Headline Inflation Rate (s.a.) }\end{array}$} & \multicolumn{4}{|c|}{ Finland } & \multicolumn{4}{|c|}{ France } \\
\hline & \multicolumn{2}{|c|}{ Potential Output } & \multicolumn{2}{|c|}{$\begin{array}{l}\text { Natural Rate of } \\
\text { Unemployment }\end{array}$} & \multicolumn{2}{|c|}{ Potential Output } & \multicolumn{2}{|c|}{$\begin{array}{l}\text { Natural Rate of } \\
\text { Unemployment }\end{array}$} \\
\hline & $\begin{array}{l}\text { Moving } \\
\text { Average }\end{array}$ & $\begin{array}{l}\text { HP } \\
\text { Filter }\end{array}$ & $\begin{array}{l}\text { HP } \\
\text { Filter }\end{array}$ & OECD & $\begin{array}{l}\text { Moving } \\
\text { Average }\end{array}$ & $\begin{array}{l}\text { HP } \\
\text { Filter }\end{array}$ & $\begin{array}{l}\text { HP } \\
\text { Filter }\end{array}$ & OECD \\
\hline$\left(\mathrm{Y}-\mathrm{Y}^{*}\right) / \mathrm{Y}^{*}$ & $\begin{array}{l}-0.04 \\
(0.06)\end{array}$ & $\begin{array}{c}-0.08 \\
(0.10)\end{array}$ & -- & -- & $\begin{array}{c}0.21 \\
(0.14)\end{array}$ & $\begin{array}{c}0.10 \\
(0.23)\end{array}$ & -- & -- \\
\hline $\mathrm{U}-\mathrm{U}^{*}$ & -- & -- & $\begin{array}{l}-0.02 \\
(0.23)\end{array}$ & $\begin{array}{l}-0.04 \\
(0.21)\end{array}$ & -- & -- & $\begin{array}{l}-0.45 \\
(0.30)\end{array}$ & $\begin{array}{l}-0.59 \\
(0.17)\end{array}$ \\
\hline$[\log (\mathrm{CPI})-\log ($ Mprice $)]$ & $\begin{array}{l}-0.09 \\
(0.01)\end{array}$ & $\begin{array}{c}-0.07 \\
(0.01)\end{array}$ & -- & $\begin{array}{l}-0.004 \\
(0.03)\end{array}$ & -- & -- & -- & -- \\
\hline$[\log (\mathrm{CPI})-\log (\mathrm{ULC})]$ & $\begin{array}{l}-0.19 \\
(0.08)\end{array}$ & $\begin{array}{l}-0.01 \\
(0.06)\end{array}$ & $\begin{array}{l}-0.08 \\
(0.03)\end{array}$ & $\begin{array}{l}-0.08 \\
(0.16)\end{array}$ & $\begin{array}{l}-0.05 \\
(0.05)\end{array}$ & $\begin{array}{l}-0.03 \\
(0.06)\end{array}$ & $\begin{array}{l}-0.03 \\
(0.06)\end{array}$ & $\begin{array}{l}-0.10 \\
(0.06)\end{array}$ \\
\hline $\mathrm{R}^{2}$ & 0.95 & 0.94 & 0.51 & 0.51 & 0.59 & 0.37 & 0.27 & 0.38 \\
\hline SER (\% a.r.) & 1.37 & 1.39 & 4.13 & 4.13 & 1.31 & 1.50 & 1.59 & 1.46 \\
\hline Residual Properties (p-values) & & & & & & & & \\
\hline Serial Independence & 0.88 & 0.66 & 0.67 & 0.07 & 0.98 & 0.60 & 0.09 & 0.29 \\
\hline Homoskedasticity & 0.78 & 0.85 & 0.18 & 0.18 & 0.93 & 0.65 & 0.66 & 0.82 \\
\hline Normality & 0.19 & 0.26 & 0.00 & 0.00 & 0.81 & 0.00 & 0.00 & 0.00 \\
\hline Sample & $80-94$ & $80-94$ & $80-94$ & $80-94$ & $79-94$ & 79-94 & 79-94 & 79-94 \\
\hline
\end{tabular}

${ }^{a}$ Entries correspond to the significance level to reject the associated hypothesis; an entry of 0.05 means that one can reject the hypothesis with a 5 percent significance level. Serial Independence: F-test for the hypothesis that all of the coefficients of an AR(5) for the residuals are equal to zero. Homoskedasticity: ARCH t-test. Normality: Jarque-Bera chi-squared test.

Y: Real GDP

$Y^{*}$ : Potential GDP

U: Unemployment rate

$\mathrm{U}^{*}$ : Natural Rate of Unemployment

CPI: Level of headline CPI

ULC: Level of unit-labor cost

Mprice: Level of import prices

Moving averages use contemporaneous and lags of 12 quarters GDP. 
Table 5: OLS Coefficient Estimates and Residual Properties

Sensitivity to Measures of Slack

(standard errors in parentheses)

\begin{tabular}{|c|c|c|c|c|c|c|c|c|}
\hline \multirow[t]{3}{*}{$\begin{array}{l}\text { Dependent Variable is } \\
\text { Headline Inflation Rate (s.a.) }\end{array}$} & \multicolumn{4}{|c|}{ Germany } & \multicolumn{4}{|c|}{ Greece } \\
\hline & \multicolumn{2}{|c|}{ Potential Output } & \multicolumn{2}{|c|}{$\begin{array}{l}\text { Natural Rate of } \\
\text { Unemployment }\end{array}$} & \multicolumn{2}{|c|}{ Potential Output } & \multicolumn{2}{|c|}{$\begin{array}{l}\text { Natural Rate of } \\
\text { Unemployment }\end{array}$} \\
\hline & $\begin{array}{l}\text { Moving } \\
\text { Average }\end{array}$ & $\begin{array}{l}\text { HP } \\
\text { Filter }\end{array}$ & $\begin{array}{l}\text { HP } \\
\text { Filter }\end{array}$ & OECD & $\begin{array}{l}\text { Moving } \\
\text { Average }\end{array}$ & $\begin{array}{l}\text { HP } \\
\text { Filter }\end{array}$ & $\begin{array}{l}\text { HP } \\
\text { Filter }\end{array}$ & OECD \\
\hline$\left(\mathrm{Y}-\mathrm{Y}^{*}\right) / \mathrm{Y}^{*}$ & $\begin{array}{c}0.04 \\
(0.06)\end{array}$ & $\begin{array}{l}-0.04 \\
(0.10)\end{array}$ & -- & -- & $\begin{array}{c}0.31 \\
(0.26)\end{array}$ & $\begin{array}{c}0.30 \\
(0.32)\end{array}$ & -- & -- \\
\hline $\mathrm{U}-\mathrm{U}^{*}$ & -- & -- & $\begin{array}{l}-0.89 \\
(0.21)\end{array}$ & $\begin{array}{l}-0.45 \\
(0.11)\end{array}$ & -- & -- & $\begin{array}{l}-3.80 \\
(1.06)\end{array}$ & $\begin{array}{l}-3.61 \\
(0.91)\end{array}$ \\
\hline$[\log (\mathrm{CPI})-\log ($ Mprice $)]$ & -- & -- & $\begin{array}{l}+0.02 \\
(0.02)\end{array}$ & $\begin{array}{l}-0.01 \\
(0.02)\end{array}$ & $\begin{array}{l}-0.23 \\
(0.15)\end{array}$ & $\begin{array}{l}-0.26 \\
(0.14)\end{array}$ & $\begin{array}{l}-0.58 \\
(0.17)\end{array}$ & $\begin{array}{l}-0.59 \\
(0.16)\end{array}$ \\
\hline$[\log (\mathrm{CPI})-\log (\mathrm{ULC})]$ & $\begin{array}{l}-0.23 \\
(0.08)\end{array}$ & $\begin{array}{l}-0.21 \\
(0.08)\end{array}$ & $\begin{array}{l}+0.09 \\
(0.07)\end{array}$ & $\begin{array}{l}-0.01 \\
(0.08)\end{array}$ & $\begin{array}{l}-0.50 \\
(0.12)\end{array}$ & $\begin{array}{l}-0.50 \\
(0.12)\end{array}$ & $\begin{array}{l}-0.27 \\
(0.18)\end{array}$ & $\begin{array}{l}-0.22 \\
(0.17)\end{array}$ \\
\hline $\begin{array}{l}\mathrm{R}^{2} \\
\text { SER (\% a.r.) }\end{array}$ & $\begin{array}{l}0.78 \\
1.35\end{array}$ & $\begin{array}{l}0.75 \\
1.42\end{array}$ & $\begin{array}{l}0.73 \\
1.42\end{array}$ & $\begin{array}{l}0.73 \\
1.44\end{array}$ & $\begin{array}{l}0.64 \\
3.01\end{array}$ & $\begin{array}{l}0.64 \\
3.03\end{array}$ & $\begin{array}{l}0.55 \\
3.27\end{array}$ & $\begin{array}{l}0.57 \\
3.18\end{array}$ \\
\hline $\begin{array}{l}\text { Residual Properties (p-values) } \\
\text { Serial Independence } \\
\text { Homoskedasticity } \\
\text { Normality }\end{array}$ & $\begin{array}{l}0.49 \\
0.34 \\
0.19\end{array}$ & $\begin{array}{l}0.50 \\
0.60 \\
0.26\end{array}$ & $\begin{array}{l}0.01 \\
0.35 \\
0.50\end{array}$ & $\begin{array}{l}0.02 \\
0.27 \\
0.49\end{array}$ & $\begin{array}{l}0.39 \\
0.79 \\
0.04\end{array}$ & $\begin{array}{l}0.42 \\
0.77 \\
0.05\end{array}$ & $\begin{array}{l}0.26 \\
0.96 \\
0.00\end{array}$ & $\begin{array}{l}0.27 \\
0.93 \\
0.01\end{array}$ \\
\hline Sample & 74-94 & 74-94 & $72-94$ & $72-94$ & $82-94$ & $82-94$ & $82-94$ & $82-94$ \\
\hline
\end{tabular}

${ }^{a}$ Entries correspond to the significance level to reject the associated hypothesis; an entry of 0.05 means that one can reject the hypothesis with a 5 percent significance level. Serial Independence: F-test for the hypothesis that all of the coefficients of an AR(5) for the residuals are equal to zero. Homoskedasticity: ARCH t-test. Normality: Jarque-Bera chi-squared test.

Y: Real GDP

$Y^{*}$ : Potential GDP

U: Unemployment rate

$\mathrm{U}^{*}$ : Natural Rate of Unemployment

CPI: Level of headline CPI

ULC: Level of unit-labor cost

Mprice: Level of import prices

Moving averages use contemporaneous and lags of 12 quarters GDP. 
Table 5: OLS Coefficient Estimates and Residual Properties

Sensitivity to Measures of Slack

(standard errors in parentheses)

\begin{tabular}{|c|c|c|c|c|c|c|c|c|}
\hline \multirow{3}{*}{$\begin{array}{l}\text { Dependent Variable is } \\
\text { Headline Inflation Rate (s.a.) }\end{array}$} & \multicolumn{4}{|c|}{ Ireland } & \multicolumn{4}{|c|}{ Italy } \\
\hline & \multicolumn{2}{|c|}{ Potential Output } & \multicolumn{2}{|c|}{$\begin{array}{l}\text { Natural Rate of } \\
\text { Unemployment }\end{array}$} & \multicolumn{2}{|c|}{ Potential Output } & \multicolumn{2}{|c|}{$\begin{array}{l}\text { Natural Rate of } \\
\text { Unemployment }\end{array}$} \\
\hline & $\begin{array}{l}\text { Moving } \\
\text { Average }\end{array}$ & $\begin{array}{l}\text { HP } \\
\text { Filter }\end{array}$ & $\begin{array}{l}\text { HP } \\
\text { Filter }\end{array}$ & OECD & $\begin{array}{l}\text { Moving } \\
\text { Average }\end{array}$ & $\begin{array}{l}\text { HP } \\
\text { Filter }\end{array}$ & $\begin{array}{l}\text { HP } \\
\text { Filter }\end{array}$ & OECD \\
\hline$\left(\mathrm{Y}-\mathrm{Y}^{*}\right) / \mathrm{Y}^{*}$ & $\begin{array}{c}0.76 \\
(0.26)\end{array}$ & $\begin{array}{l}-0.12 \\
(0.17)\end{array}$ & -- & -- & $\begin{array}{c}0.08 \\
(0.22)\end{array}$ & $\begin{array}{c}0.19 \\
(0.36)\end{array}$ & -- & -- \\
\hline $\mathrm{U}-\mathrm{U}^{*}$ & -- & -- & $\begin{array}{l}-0.19 \\
(0.55)\end{array}$ & $\begin{array}{l}-0.32 \\
(0.44)\end{array}$ & -- & -- & $\begin{array}{c}0.25 \\
(0.58)\end{array}$ & $\begin{array}{l}-0.39 \\
(0.40)\end{array}$ \\
\hline$[\log (\mathrm{CPI})-\log ($ Mprice $)]$ & -- & $\begin{array}{l}-0.02 \\
(0.01)\end{array}$ & $\begin{array}{l}-0.03 \\
(0.02)\end{array}$ & $\begin{array}{l}-0.02 \\
(0.02)\end{array}$ & $\begin{array}{l}+0.03 \\
(0.01)\end{array}$ & $\begin{array}{l}+0.02 \\
(0.01)\end{array}$ & $\begin{array}{l}+0.03 \\
(0.01)\end{array}$ & $\begin{array}{l}+0.03 \\
(0.01)\end{array}$ \\
\hline$[\log (\mathrm{CPI})-\log (\mathrm{ULC})]$ & $\begin{array}{l}-0.21 \\
(0.09)\end{array}$ & -- & $\begin{array}{l}-0.01 \\
(0.06)\end{array}$ & $\begin{array}{l}-0.04 \\
(0.06)\end{array}$ & $\begin{array}{l}-0.24 \\
(0.13)\end{array}$ & -- & -- & -- \\
\hline $\mathrm{R}^{2}$ & 0.72 & 0.68 & 0.78 & 0.79 & 0.67 & 0.42 & 0.49 & 0.52 \\
\hline SER (\% a.r.) & 2.76 & 2.81 & 2.44 & 2.38 & 2.32 & 2.94 & 2.75 & 2.68 \\
\hline $\begin{array}{l}\text { Residual Properties (p-values) } \\
\text { Serial Independence } \\
\text { Homoskedasticity } \\
\text { Normality }\end{array}$ & $\begin{array}{l}0.53 \\
0.06 \\
0.00\end{array}$ & $\begin{array}{l}0.45 \\
0.01 \\
0.00\end{array}$ & $\begin{array}{l}0.45 \\
0.19 \\
0.01\end{array}$ & $\begin{array}{l}0.36 \\
0.25 \\
0.01\end{array}$ & $\begin{array}{l}0.89 \\
0.38 \\
0.48\end{array}$ & $\begin{array}{l}0.55 \\
0.00 \\
0.60\end{array}$ & $\begin{array}{l}0.86 \\
0.21 \\
0.28\end{array}$ & $\begin{array}{l}0.80 \\
0.20 \\
0.23\end{array}$ \\
\hline Sample & $81-94$ & $81-94$ & $81-94$ & $81-94$ & 74-94 & 74-94 & $72-94$ & $72-94$ \\
\hline
\end{tabular}

${ }^{a}$ Entries correspond to the significance level to reject the associated hypothesis; an entry of 0.05 means that one can reject the hypothesis with a 5 percent significance level. Serial Independence: F-test for the hypothesis that all of the coefficients of an AR(5) for the residuals are equal to zero. Homoskedasticity: ARCH t-test. Normality: Jarque-Bera chi-squared test.

Y: Real GDP

$\mathrm{Y}^{*}$ : Potential GDP

$\mathrm{U}$ : Unemployment rate

$\mathrm{U}^{*}$ : Natural Rate of Unemployment

CPI: Level of headline CPI

ULC: Level of unit-labor cost

Mprice: Level of import prices

Moving averages use contemporaneous and lags of 12 quarters GDP. 
Table 5: OLS Coefficient Estimates and Residual Properties

Sensitivity to Measures of Slack

(standard errors in parentheses)

\begin{tabular}{|c|c|c|c|c|c|c|c|c|}
\hline \multirow[t]{3}{*}{$\begin{array}{l}\text { Dependent Variable is } \\
\text { Headline Inflation Rate (s.a.) }\end{array}$} & \multicolumn{4}{|c|}{ Japan } & \multicolumn{4}{|c|}{ Netherlands } \\
\hline & \multicolumn{2}{|c|}{ Potential Output } & \multicolumn{2}{|c|}{$\begin{array}{l}\text { Natural Rate of } \\
\text { Unemployment }\end{array}$} & \multicolumn{2}{|c|}{ Potential Output } & \multicolumn{2}{|c|}{$\begin{array}{l}\text { Natural Rate of } \\
\text { Unemployment }\end{array}$} \\
\hline & $\begin{array}{l}\text { Moving } \\
\text { Average }\end{array}$ & $\begin{array}{l}\text { HP } \\
\text { Filter }\end{array}$ & $\begin{array}{l}\text { HP } \\
\text { Filter }\end{array}$ & OECD & $\begin{array}{l}\text { Moving } \\
\text { Average }\end{array}$ & $\begin{array}{l}\text { HP } \\
\text { Filter }\end{array}$ & $\begin{array}{l}\text { HP } \\
\text { Filter }\end{array}$ & OECD \\
\hline$\left(\mathrm{Y}-\mathrm{Y}^{*}\right) / \mathrm{Y}^{*}$ & $\begin{array}{c}0.13 \\
(0.09)\end{array}$ & $\begin{array}{c}0.29 \\
(0.17)\end{array}$ & -- & -- & $\begin{array}{c}0.09 \\
(0.09)\end{array}$ & $\begin{array}{c}0.18 \\
(0.15)\end{array}$ & -- & -- \\
\hline $\mathrm{U}-\mathrm{U}^{*}$ & -- & -- & $\begin{array}{l}-1.07 \\
(1.59)\end{array}$ & $\begin{array}{l}-2.77 \\
(0.83)\end{array}$ & -- & -- & $\begin{array}{l}-0.47 \\
(0.20)\end{array}$ & $\begin{array}{l}-0.44 \\
(0.15)\end{array}$ \\
\hline$[\log (\mathrm{CPI})-\log ($ Mprice $)]$ & $\begin{array}{l}+0.01 \\
(0.01)\end{array}$ & -- & -- & $\begin{array}{l}-0.01 \\
(0.01)\end{array}$ & -- & -- & -- & -- \\
\hline$[\log (\mathrm{CPI})-\log (\mathrm{ULC})]$ & $\begin{array}{l}+0.04 \\
(0.09)\end{array}$ & $\begin{array}{l}+0.14 \\
(0.07)\end{array}$ & -- & -- & -- & -- & $\begin{array}{l}+0.01 \\
(0.01\end{array}$ & $\begin{array}{l}-0.01 \\
(0.02)\end{array}$ \\
\hline $\begin{array}{l}\mathrm{R}^{2} \\
\text { SER (\% a.r.) }\end{array}$ & $\begin{array}{l}0.69 \\
1.34\end{array}$ & $\begin{array}{l}0.64 \\
1.44\end{array}$ & $\begin{array}{l}0.50 \\
2.60\end{array}$ & $\begin{array}{l}0.61 \\
2.30\end{array}$ & $\begin{array}{l}0.39 \\
1.57\end{array}$ & $\begin{array}{l}0.40 \\
1.55\end{array}$ & $\begin{array}{l}0.39 \\
1.52\end{array}$ & $\begin{array}{l}0.40 \\
1.51\end{array}$ \\
\hline Residual Properties (p-values) & & & & & & & & \\
\hline Serial Independence & 0.04 & 0.32 & 0.09 & 0.11 & 0.94 & 0.98 & 0.70 & 0.68 \\
\hline Homoskedasticity & 0.88 & 0.00 & 0.00 & 0.02 & 0.99 & 0.72 & 0.95 & 0.98 \\
\hline Normality & 0.02 & 0.00 & 0.00 & 0.00 & 0.49 & 0.50 & 0.40 & 0.43 \\
\hline Sample & $75-94$ & $75-94$ & $72-94$ & $72-94$ & $75-94$ & $75-94$ & 73-94 & 73-94 \\
\hline
\end{tabular}

${ }^{a}$ Entries correspond to the significance level to reject the associated hypothesis; an entry of 0.05 means that one can reject the hypothesis with a 5 percent significance level. Serial Independence: F-test for the hypothesis that all of the coefficients of an AR(5) for the residuals are equal to zero. Homoskedasticity: ARCH t-test. Normality: Jarque-Bera chi-squared test.

Y: Real GDP

$\mathrm{Y}^{*}$ : Potential GDP

$\mathrm{U}$ : Unemployment rate

U*: Natural Rate of Unemployment

CPI: Level of headline CPI

ULC: Level of unit-labor cost

Mprice: Level of import prices

Moving averages use contemporaneous and lags of 12 quarters GDP. 
Table 5: OLS Coefficient Estimates and Residual Properties Sensitivity to Measures of Slack (standard errors in parentheses)

\begin{tabular}{|c|c|c|c|c|c|c|c|c|}
\hline \multirow[t]{3}{*}{$\begin{array}{l}\text { Dependent Variable is } \\
\text { Headline Inflation Rate (s.a.) }\end{array}$} & \multicolumn{4}{|c|}{$\begin{array}{l}\text { New } \\
\text { Zealand }\end{array}$} & \multicolumn{4}{|c|}{ Norway } \\
\hline & \multicolumn{2}{|c|}{ Potential Output } & \multicolumn{2}{|c|}{$\begin{array}{l}\text { Natural Rate of } \\
\text { Unemployment }\end{array}$} & \multicolumn{2}{|c|}{ Potential Output } & \multicolumn{2}{|c|}{$\begin{array}{l}\text { Natural Rate of } \\
\text { Unemployment }\end{array}$} \\
\hline & $\begin{array}{l}\text { Moving } \\
\text { Average }\end{array}$ & $\begin{array}{l}\text { HP } \\
\text { Filter }\end{array}$ & $\begin{array}{l}\text { HP } \\
\text { Filter }\end{array}$ & OECD & $\begin{array}{l}\text { Moving } \\
\text { Average }\end{array}$ & $\begin{array}{l}\text { HP } \\
\text { Filter }\end{array}$ & $\begin{array}{l}\text { HP } \\
\text { Filter }\end{array}$ & OECD \\
\hline$\left(\mathrm{Y}-\mathrm{Y}^{*}\right) / \mathrm{Y}^{*}$ & $\begin{array}{c}0.59 \\
(0.34)\end{array}$ & $\begin{array}{l}1.15 \\
(0.44)\end{array}$ & -- & -- & $\begin{array}{c}0.41 \\
(0.13)\end{array}$ & $\begin{array}{c}0.93 \\
(0.21)\end{array}$ & -- & -- \\
\hline $\mathrm{U}-\mathrm{U}^{*}$ & -- & -- & $\begin{array}{l}-2.34 \\
(1.08)\end{array}$ & $\begin{array}{l}-1.86 \\
(0.87)\end{array}$ & -- & -- & $\begin{array}{l}-1.44 \\
(0.45)\end{array}$ & $\begin{array}{l}-1.58 \\
(0.43)\end{array}$ \\
\hline$[\log (\mathrm{CPI})-\log ($ Mprice $)]$ & $\begin{array}{l}-0.03 \\
(0.08)\end{array}$ & $\begin{array}{l}-0.30 \\
(0.09)\end{array}$ & $\begin{array}{l}-0.38 \\
(0.16)\end{array}$ & $\begin{array}{l}-0.27 \\
(0.17)\end{array}$ & $\begin{array}{l}-0.06 \\
(0.03)\end{array}$ & $\begin{array}{l}-0.06 \\
(0.02)\end{array}$ & $\begin{array}{l}-0.06 \\
(0.02)\end{array}$ & $\begin{array}{l}-0.06 \\
(0.02)\end{array}$ \\
\hline$[\log (\mathrm{CPI})-\log (\mathrm{ULC})]$ & -- & $\begin{array}{l}+0.67 \\
(0.20)\end{array}$ & -- & -- & $\begin{array}{l}+0.12 \\
(0.06)\end{array}$ & -- & -- & -- \\
\hline $\mathrm{R}^{2}$ & 0.82 & 0.87 & 0.78 & 0.78 & 0.66 & 0.70 & 0.54 & 0.56 \\
\hline SER (\% a.r.) & 3.59 & 3.00 & 4.01 & 4.02 & 1.87 & 1.83 & 2.19 & 2.14 \\
\hline Residual Properties (p-values) & & & & & & & & \\
\hline Serial Independence & 0.65 & 0.31 & 0.96 & 0.92 & 0.29 & 0.73 & 0.92 & 0.94 \\
\hline Homoskedasticity & 0.97 & 0.99 & 0.88 & 0.88 & 0.95 & 0.97 & 0.97 & 0.97 \\
\hline Normality & 0.06 & 0.00 & 0.22 & 0.17 & 0.02 & 0.00 & 0.00 & 0.00 \\
\hline Sample & $86-94$ & 86-94 & $86-94$ & $86-94$ & 74-94 & 73-94 & 73-94 & 73-94 \\
\hline
\end{tabular}

${ }^{a}$ Entries correspond to the significance level to reject the associated hypothesis; an entry of 0.05 means that one can reject the hypothesis with a 5 percent significance level. Serial Independence: F-test for the hypothesis that all of the coefficients of an AR(5) for the residuals are equal to zero. Homoskedasticity: ARCH t-test. Normality: Jarque-Bera chi-squared test.

Y: Real GDP

$Y^{*}$ : Potential GDP

U: Unemployment rate

$\mathrm{U}^{*}$ : Natural Rate of Unemployment

CPI: Level of headline CPI

ULC: Level of unit-labor cost

Mprice: Level of import prices

Moving averages use contemporaneous and lags of 12 quarters GDP. 
Table 5: OLS Coefficient Estimates and Residual Properties

Sensitivity to Measures of Slack

(standard errors in parentheses)

\begin{tabular}{|c|c|c|c|c|c|c|c|c|}
\hline \multirow[t]{3}{*}{$\begin{array}{l}\text { Dependent Variable is } \\
\text { Headline Inflation Rate (s.a.) }\end{array}$} & \multicolumn{4}{|c|}{ Portugal } & \multicolumn{4}{|c|}{ Spain } \\
\hline & \multicolumn{2}{|c|}{ Potential Output } & \multicolumn{2}{|c|}{$\begin{array}{l}\text { Natural Rate of } \\
\text { Unemployment }\end{array}$} & \multicolumn{2}{|c|}{ Potential Output } & \multicolumn{2}{|c|}{$\begin{array}{l}\text { Natural Rate of } \\
\text { Unemployment }\end{array}$} \\
\hline & $\begin{array}{l}\text { Moving } \\
\text { Average }\end{array}$ & $\begin{array}{l}\text { HP } \\
\text { Filter }\end{array}$ & $\begin{array}{l}\text { HP } \\
\text { Filter }\end{array}$ & OECD & $\begin{array}{l}\text { Moving } \\
\text { Average }\end{array}$ & $\begin{array}{l}\text { HP } \\
\text { Filter }\end{array}$ & $\begin{array}{l}\text { HP } \\
\text { Filter }\end{array}$ & OECD \\
\hline$\left(\mathrm{Y}-\mathrm{Y}^{*}\right) / \mathrm{Y}^{*}$ & $\begin{array}{c}0.56 \\
(0.17)\end{array}$ & $\begin{array}{c}0.91 \\
(0.31)\end{array}$ & -- & -- & $\begin{array}{c}0.33 \\
(0.12)\end{array}$ & $\begin{array}{c}0.45 \\
(0.21)\end{array}$ & -- & -- \\
\hline $\mathrm{U}-\mathrm{U}^{*}$ & -- & -- & $\begin{array}{l}-1.02 \\
(0.67)\end{array}$ & $\begin{array}{l}-1.07 \\
(0.46)\end{array}$ & -- & -- & $\begin{array}{l}-0.15 \\
(0.13)\end{array}$ & $\begin{array}{l}-0.12 \\
(0.09)\end{array}$ \\
\hline$[\log (\mathrm{CPI})-\log ($ Mprice $)]$ & -- & -- & -- & -- & -- & -- & -- & -- \\
\hline$[\log (\mathrm{CPI})-\log (\mathrm{ULC})]$ & $\begin{array}{l}-0.11 \\
(0.12)\end{array}$ & $\begin{array}{l}-0.17 \\
(0.13)\end{array}$ & $\begin{array}{l}+0.04 \\
(0.12)\end{array}$ & $\begin{array}{l}-0.05 \\
(0.13)\end{array}$ & $\begin{array}{l}-0.17 \\
(0.06)\end{array}$ & $\begin{array}{l}-0.06 \\
(0.05)\end{array}$ & $\begin{array}{l}-0.02 \\
(0.05)\end{array}$ & $\begin{array}{l}-0.02 \\
(0.04)\end{array}$ \\
\hline $\begin{array}{l}\mathrm{R}^{2} \\
\mathrm{SER}(\% \text { a.r.) }\end{array}$ & $\begin{array}{l}0.62 \\
3.50\end{array}$ & $\begin{array}{l}0.56 \\
3.62\end{array}$ & $\begin{array}{l}0.51 \\
3.81\end{array}$ & $\begin{array}{l}0.55 \\
3.68\end{array}$ & $\begin{array}{l}0.58 \\
1.89\end{array}$ & $\begin{array}{l}0.55 \\
1.94\end{array}$ & $\begin{array}{l}0.46 \\
2.05\end{array}$ & $\begin{array}{l}0.47 \\
2.05\end{array}$ \\
\hline $\begin{array}{l}\text { Residual Properties (p-values) } \\
\text { Serial Independence } \\
\text { Homoskedasticity } \\
\text { Normality }\end{array}$ & $\begin{array}{l}0.45 \\
0.59 \\
0.25\end{array}$ & $\begin{array}{l}0.32 \\
0.39 \\
0.46\end{array}$ & $\begin{array}{l}0.16 \\
0.58 \\
0.17\end{array}$ & $\begin{array}{l}0.16 \\
0.56 \\
0.33\end{array}$ & $\begin{array}{l}0.30 \\
0.94 \\
0.15\end{array}$ & $\begin{array}{l}0.19 \\
0.98 \\
0.15\end{array}$ & $\begin{array}{l}0.06 \\
0.92 \\
0.17\end{array}$ & $\begin{array}{l}0.05 \\
0.92 \\
0.15\end{array}$ \\
\hline Sample & 84-94 & $84-94$ & 84-94 & 84-94 & 79-94 & 79-94 & 74-94 & $79-94$ \\
\hline
\end{tabular}

${ }^{a}$ Entries correspond to the significance level to reject the associated hypothesis; an entry of 0.05 means that one can reject the hypothesis with a 5 percent significance level. Serial Independence: F-test for the hypothesis that all of the coefficients of an AR(5) for the residuals are equal to zero. Homoskedasticity: ARCH t-test. Normality: Jarque-Bera chi-squared test.

Y: Real GDP

$Y^{*}:$ Potential GDP

U: Unemployment rate

$\mathrm{U}^{*}$ : Natural Rate of Unemployment

CPI: Level of headline CPI

ULC: Level of unit-labor cost

Mprice: Level of import prices

Moving averages use contemporaneous and lags of 12 quarters GDP. 
Table 5: OLS Coefficient Estimates and Residual Properties Sensitivity to Measures of Slack (standard errors in parentheses)

\begin{tabular}{|c|c|c|c|c|c|c|c|c|}
\hline \multirow[t]{3}{*}{$\begin{array}{l}\text { Dependent Variable is } \\
\text { Headline Inflation Rate (s.a.) }\end{array}$} & \multicolumn{4}{|c|}{ Sweden } & \multicolumn{4}{|c|}{ Switzerland } \\
\hline & \multicolumn{2}{|c|}{ Potential Output } & \multicolumn{2}{|c|}{$\begin{array}{l}\text { Natural Rate of } \\
\text { Unemployment }\end{array}$} & \multicolumn{2}{|c|}{ Potential Output } & \multicolumn{2}{|c|}{$\begin{array}{l}\text { Natural Rate of } \\
\text { Unemployment }\end{array}$} \\
\hline & $\begin{array}{l}\text { Moving } \\
\text { Average }\end{array}$ & $\begin{array}{l}\text { HP } \\
\text { Filter }\end{array}$ & $\begin{array}{l}\text { HP } \\
\text { Filter }\end{array}$ & OECD & $\begin{array}{l}\text { Moving } \\
\text { Average }\end{array}$ & $\begin{array}{l}\text { HP } \\
\text { Filter }\end{array}$ & $\begin{array}{l}\text { HP } \\
\text { Filter }\end{array}$ & OECD \\
\hline$\left(\mathrm{Y}-\mathrm{Y}^{*}\right) / \mathrm{Y}^{*}$ & $\begin{array}{c}0.47 \\
(0.21)\end{array}$ & $\begin{array}{c}0.50 \\
(0.27)\end{array}$ & -- & -- & $\begin{array}{c}0.32 \\
(0.13)\end{array}$ & $\begin{array}{c}0.61 \\
(0.23)\end{array}$ & -- & -- \\
\hline $\mathrm{U}-\mathrm{U}^{*}$ & -- & -- & $\begin{array}{l}-0.17 \\
(0.40)\end{array}$ & $\begin{array}{l}-0.25 \\
(0.29)\end{array}$ & -- & -- & $\begin{array}{c}-0.31 \\
(0.42)\end{array}$ & $\begin{array}{l}-0.28 \\
(0.26)\end{array}$ \\
\hline$[\log (\mathrm{CPI})-\log ($ Mprice $)]$ & $\begin{array}{l}+0.04 \\
(0.03)\end{array}$ & -- & -- & -- & -- & -- & -- & -- \\
\hline$[\log (\mathrm{CPI})-\log (\mathrm{ULC})]$ & $\begin{array}{l}-0.16 \\
(0.07)\end{array}$ & $\begin{array}{l}-0.02 \\
(0.07)\end{array}$ & $\begin{array}{l}-0.01 \\
(0.08)\end{array}$ & $\begin{array}{l}-0.02 \\
(0.07)\end{array}$ & $\begin{array}{l}-0.04 \\
(0.08)\end{array}$ & $\begin{array}{l}-0.18 \\
(0.11)\end{array}$ & $\begin{array}{l}+0.02 \\
(0.08)\end{array}$ & $\begin{array}{l}-0.05 \\
(0.08)\end{array}$ \\
\hline $\mathrm{R}^{2}$ & 0.64 & 0.46 & 0.51 & 0.53 & 0.24 & 0.30 & 0.20 & 0.26 \\
\hline SER ( $\%$ a.r.) & 3.20 & 3.65 & 3.45 & 3.41 & 1.93 & 1.92 & 1.99 & 1.92 \\
\hline $\begin{array}{l}\text { Residual Properties (p-values) } \\
\text { Serial Independence } \\
\text { Homoskedasticity } \\
\text { Normality }\end{array}$ & $\begin{array}{l}0.30 \\
0.41 \\
0.05\end{array}$ & $\begin{array}{l}0.67 \\
0.64 \\
0.02\end{array}$ & $\begin{array}{l}0.84 \\
0.51 \\
0.01\end{array}$ & $\begin{array}{l}0.85 \\
0.37 \\
0.01\end{array}$ & $\begin{array}{l}0.61 \\
0.22 \\
0.37\end{array}$ & $\begin{array}{l}0.43 \\
0.02 \\
0.37\end{array}$ & $\begin{array}{l}0.55 \\
0.47 \\
0.14\end{array}$ & $\begin{array}{l}0.53 \\
0.51 \\
0.25\end{array}$ \\
\hline Sample & 74-94 & $72-94$ & $72-94$ & $72-94$ & $79-94$ & 79-94 & 79-94 & 79-94 \\
\hline
\end{tabular}

${ }^{a}$ Entries correspond to the significance level to reject the associated hypothesis; an entry of 0.05 means that one can reject the hypothesis with a 5 percent significance level. Serial Independence: F-test for the hypothesis that all of the coefficients of an AR(5) for the residuals are equal to zero. Homoskedasticity: ARCH t-test. Normality: Jarque-Bera chi-squared test.

Y: Real GDP

$Y^{*}$ : Potential GDP

U: Unemployment rate

$\mathrm{U}^{*}$ : Natural Rate of Unemployment

CPI: Level of headline CPI

ULC: Level of unit-labor cost

Mprice: Level of import prices

Moving averages use contemporaneous and lags of 12 quarters GDP. 
Table 5: OLS Coefficient Estimates and Residual Properties Sensitivity to Measures of Slack (standard errors in parentheses)

\begin{tabular}{|c|c|c|c|c|c|c|c|c|}
\hline \multirow[t]{3}{*}{$\begin{array}{l}\text { Dependent Variable is } \\
\text { Headline Inflation Rate (s.a.) }\end{array}$} & \multicolumn{4}{|c|}{$\begin{array}{l}\text { United } \\
\text { Kingdom }\end{array}$} & \multicolumn{4}{|c|}{$\begin{array}{r}\text { United } \\
\text { States }\end{array}$} \\
\hline & \multicolumn{2}{|c|}{ Potential Output } & \multicolumn{2}{|c|}{$\begin{array}{l}\text { Natural Rate of } \\
\text { Unemployment }\end{array}$} & \multicolumn{2}{|c|}{ Potential Output } & \multicolumn{2}{|c|}{$\begin{array}{l}\text { Natural Rate of } \\
\text { Unemployment }\end{array}$} \\
\hline & $\begin{array}{l}\text { Moving } \\
\text { Average }\end{array}$ & $\begin{array}{l}\text { HP } \\
\text { Filter }\end{array}$ & $\begin{array}{l}\text { HP } \\
\text { Filter }\end{array}$ & OECD & $\begin{array}{l}\text { Moving } \\
\text { Average }\end{array}$ & $\begin{array}{l}\text { HP } \\
\text { Filter }\end{array}$ & $\begin{array}{l}\mathrm{HP} \\
\text { Filter }\end{array}$ & OECD \\
\hline \multicolumn{9}{|l|}{ Sum of Coefficients for } \\
\hline$\left(\mathrm{Y}-\mathrm{Y}^{*}\right) / \mathrm{Y}^{*}$ & $\begin{array}{c}0.70 \\
(0.13)\end{array}$ & $\begin{array}{c}0.48 \\
(0.20)\end{array}$ & -- & -- & $\begin{array}{c}0.20 \\
(0.10)\end{array}$ & $\begin{array}{c}0.53 \\
(0.14)\end{array}$ & -- & -- \\
\hline $\mathrm{U}-\mathrm{U}^{*}$ & -- & -- & $\begin{array}{l}-0.07 \\
(0.15)\end{array}$ & $\begin{array}{l}-0.15 \\
(0.12)\end{array}$ & -- & -- & $\begin{array}{l}-0.52 \\
(0.21)\end{array}$ & $\begin{array}{l}-0.38 \\
(0.19)\end{array}$ \\
\hline$[\log (\mathrm{CPI})-\log ($ Mprice $)]$ & $\begin{array}{l}+0.05 \\
(0.02)\end{array}$ & -- & -- & -- & $\begin{array}{l}+0.07 \\
(0.03)\end{array}$ & $\begin{array}{l}+0.07 \\
(0.02)\end{array}$ & $\begin{array}{l}+0.09 \\
(0.03)\end{array}$ & $\begin{array}{l}+0.07 \\
(0.03)\end{array}$ \\
\hline$[\log (\mathrm{CPI})-\log (\mathrm{ULC})]$ & $\begin{array}{l}-0.38 \\
(0.12)\end{array}$ & -- & -- & -- & $\begin{array}{l}-0.20 \\
(0.08)\end{array}$ & $\begin{array}{l}-0.21 \\
(0.07)\end{array}$ & $\begin{array}{l}-0.21 \\
(0.08)\end{array}$ & $\begin{array}{l}-0.19 \\
(0.08)\end{array}$ \\
\hline $\begin{array}{l}\mathrm{R}^{2} \\
\text { SER (\% a.r.) }\end{array}$ & $\begin{array}{l}0.85 \\
1.71\end{array}$ & $\begin{array}{l}0.81 \\
1.97\end{array}$ & $\begin{array}{l}0.81 \\
1.92\end{array}$ & $\begin{array}{l}0.81 \\
1.92\end{array}$ & $\begin{array}{l}0.47 \\
1.65\end{array}$ & $\begin{array}{l}0.54 \\
1.56\end{array}$ & $\begin{array}{l}0.65 \\
1.38\end{array}$ & $\begin{array}{l}0.64 \\
1.40\end{array}$ \\
\hline Residual Properties (p-values) & & & & & & & & \\
\hline Serial Independence & 0.20 & 0.10 & 0.03 & 0.02 & 0.99 & 0.32 & 0.23 & 0.14 \\
\hline Homoskedasticity & 0.34 & 0.27 & 0.88 & 0.61 & 0.50 & 0.34 & 0.99 & 0.98 \\
\hline Normality & 0.06 & 0.07 & 0.02 & 0.08 & 0.27 & 0.12 & 0.52 & 0.74 \\
\hline Sample & $77-94$ & $77-94$ & 77-94 & $77-94$ & $77-94$ & $77-94$ & $77-94$ & $77-94$ \\
\hline
\end{tabular}

${ }^{a}$ Entries correspond to the significance level to reject the associated hypothesis; an entry of 0.05 means that one can reject the hypothesis with a 5 percent significance level. Serial Independence: F-test for the hypothesis that all of the coefficients of an AR(5) for the residuals are equal to zero. Homoskedasticity: ARCH t-test. Normality: Jarque-Bera chi-squared test.

Y: Real GDP

$Y^{*}:$ Potential GDP

$\mathrm{U}$ : Unemployment rate

$\mathrm{U}^{*}$ : Natural Rate of Unemployment

CPI: Level of headline CPI

ULC: Level of unit-labor cost

Mprice: Level of import prices

Moving averages use contemporaneous and lags of 12 quarters GDP. 
Table 6: One-step Ahead Prediction Errors of CPI Inflation (Actual - Predicted): Sensitivity to Model Specification

\begin{tabular}{|c|c|c|c|c|}
\hline \multirow[b]{2}{*}{ Country } & \multicolumn{2}{|c|}{$\begin{array}{c}\text { Equation 1: Phillips Curve with } \\
\text { Productivity and Time-varying } \\
\text { NAIRU }\end{array}$} & \multicolumn{2}{|c|}{$\begin{array}{c}\text { Equation 2: Standard Phillips } \\
\text { Curve }\end{array}$} \\
\hline & $\begin{array}{l}\text { Mean Forecast } \\
\text { Error }\end{array}$ & $\begin{array}{l}\text { Test of Zero } \\
\text { Mean }\end{array}$ & $\begin{array}{l}\text { Mean Forecast } \\
\text { Error }\end{array}$ & $\begin{array}{l}\text { Test of Zero } \\
\text { Mean }\end{array}$ \\
\hline Australia & -0.22 & -0.34 & -0.47 & -0.73 \\
\hline Austria & 0.47 & 1.51 & 0.01 & 0.04 \\
\hline Belgium & 0.68 & $2.52 *$ & 0.14 & 0.53 \\
\hline Canada & 0.22 & 1.04 & -0.08 & -0.35 \\
\hline Finland & 1.40 & 1.82 & 0.20 & 0.52 \\
\hline France & 0.72 & $2.61^{*}$ & 0.19 & 0.64 \\
\hline Germany & 0.74 & $2.74 *$ & 0.42 & 1.47 \\
\hline Greece & 3.60 & $5.99 *$ & 3.78 & $5.67^{*}$ \\
\hline Ireland & 0.60 & 1.33 & 5.67 & $6.98^{*}$ \\
\hline Italy & 0.18 & 0.35 & -0.05 & -0.09 \\
\hline Japan & 2.20 & $5.06^{*}$ & 1.53 & $2.88^{*}$ \\
\hline Netherlands & 0.06 & 0.21 & -0.14 & -0.47 \\
\hline New Zealand & -1.12 & -1.47 & -4.45 & $-5.64 *$ \\
\hline Norway & 0.26 & 0.65 & -0.33 & -0.68 \\
\hline Portugal & 0.96 & 1.38 & 0.70 & 1.02 \\
\hline Spain & 0.32 & 0.83 & 0.56 & 1.20 \\
\hline Sweden & -0.12 & -0.19 & -1.14 & -1.79 \\
\hline Switzerland & -0.11 & -0.30 & -0.14 & -0.34 \\
\hline United Kingdom & 0.01 & 0.02 & 0.49 & 1.35 \\
\hline United States & -0.33 & -1.25 & -0.67 & $-2.43^{*}$ \\
\hline
\end{tabular}

* Mean forecast error is significantly different from zero at the 95 percent confidence level 
Table 7: Effects of Labor-market Slack on Inflation Average Percentage Points, 1995-2001

\begin{tabular}{lccc}
\hline & Total $^{\mathrm{a}}$ & NAIRU $^{\mathrm{b}}$ & Cyclical $^{\mathrm{c}}$ \\
\hline Country & & & \\
Australia & -0.17 & -0.23 & 0.06 \\
Austria & -1.17 & 0.02 & -1.19 \\
Belgium & -0.15 & -0.05 & -0.10 \\
Canada & -0.16 & -0.41 & 0.24 \\
Finland & -0.09 & -0.03 & -0.06 \\
France & -0.65 & -0.31 & -0.34 \\
Germany & -1.30 & 0.24 & -1.54 \\
Greece & 1.81 & 0.78 & 1.03 \\
Ireland & 0.47 & -1.79 & 2.26 \\
Italy & -0.48 & -0.15 & -0.33 \\
Japan & -2.27 & 2.69 & -4.96 \\
Netherlands & 0.11 & -0.42 & 0.53 \\
New Zealand & -0.78 & -3.05 & 2.27 \\
Norway & 0.10 & -1.57 & 1.67 \\
Portugal & -1.44 & -0.15 & -1.29 \\
Spain & -0.35 & -0.25 & -0.10 \\
Sweden & -0.26 & 0.04 & -0.30 \\
Switzerland & -0.33 & 0.01 & -0.34 \\
United Kingdom & -0.03 & -0.15 & 0.12 \\
United States & 0.23 & -0.02 & 0.24 \\
\hline
\end{tabular}

${ }^{\text {a }}$ Total effect is estimated as the average of the difference between baseline inflation and the counterfactual inflation assuming that labor-market slack is absent from 1995 to 2001.

${ }^{\mathrm{b}}$ NAIRU effect is estimated as the average of the difference between baseline inflation and the counterfactual inflation assuming that the NAIRU remains at its 1994 value from 1995 to 2001.

${ }^{\text {a }}$ Cyclical effect is estimated as the difference Total effect and the NAIRU effect. 
Table A1: Recursive Chow Test Results: Frequency and Dates of Instability Alternative Samples

\begin{tabular}{|c|c|c|c|c|c|c|c|}
\hline & \multicolumn{3}{|c|}{ Estimation Sample ends in 1994:4 } & \multicolumn{3}{|c|}{ Full Sample } & Full-Sample \\
\hline & 1 quarter ahead & Contracting $^{\mathrm{b}}$ & Expanding $^{c}$ & 1 quarter ahead & Contracting $^{\mathrm{b}}$ & Expanding $^{c}$ & \\
\hline United States & 0 & 0 & 0 & 0 & 0 & 0 & 1972-2002.1 \\
\hline Australia & 0 & 0 & 0 & 0 & 0 & 0 & $1972-2002.1$ \\
\hline Austria & +1984 & 0 & 0 & $\begin{array}{c}+ \\
1984\end{array}$ & 0 & 0 & $1972-2002.1$ \\
\hline Belgium & 0 & 0 & 0 & +2001 & 0 & 0 & 1981-2001.4 \\
\hline Canada & 0 & 0 & 0 & 0 & 0 & 0 & 1977-2001.4 \\
\hline Finland & 0 & 0 & 0 & 0 & 0 & 0 & $1980-2002.2$ \\
\hline France & +1991 & 0 & 0 & $\begin{array}{c}+ \\
1991\end{array}$ & 0 & 0 & $1979-2001.3$ \\
\hline Germany & $+1983,1992$ & 0 & 0 & $+1983,1992$ & 0 & 0 & 1972-2001.1 \\
\hline Greece & 0 & 0 & 0 & 0 & 0 & 0 & 1982-1999.2 \\
\hline Ireland & 0 & 0 & 0 & 0 & 0 & 0 & 1981-2000.4 \\
\hline Italy & 0 & 0 & 0 & 0 & 0 & 0 & 1972-2001.4 \\
\hline Japan & +1978 & 0 & 0 & $++1987,97-98$ & 0 & 0 & $1972-2002.1$ \\
\hline Netherlands & +1983 & 0 & 0 & +1983 & 0 & 0 & $1973-2000.4$ \\
\hline New Zealand & 0 & 0 & 0 & 0 & 0 & 0 & $1986-2001.1$ \\
\hline Norway & 0 & 0 & 0 & +1996 & 0 & 0 & $1973-2001.4$ \\
\hline Portugal & 0 & 0 & 0 & 0 & 0 & 0 & $1984-2002.1$ \\
\hline Spain & 0 & 0 & 0 & 0 & 0 & 0 & $1979-2002.1$ \\
\hline Sweden & 0 & 0 & 0 & 0 & 0 & 0 & $1972-2000.2$ \\
\hline Switzerland & 0 & 0 & 0 & 0 & 0 & 0 & $1979-2002.2$ \\
\hline United Kingdom & +1990 & 0 & 0 & +1994 & 0 & 0 & $1977-2002.1$ \\
\hline
\end{tabular}

An entry of " 0 " denotes no rejections of the hypothesis of parameter stability for the period considered. An entry of "+" denotes one or two rejections of the hypothesis of parameter stability for the period considered; "++" denotes half-dozen rejections of the hypothesis of parameter stability; "+++" denotes numerous rejections of the hypothesis of parameter stability.

${ }^{\mathrm{b}}$ Forecast horizon contracts, one quarter at a time, as the estimation sample increases.

${ }^{\mathrm{c}}$ Forecast horizon expands, one quarter at a time, as the estimation sample increases. 
Table A2: OLS Coefficient Estimates and Residual Properties for Standard Phillips Curve (standard errors in parentheses)

\begin{tabular}{|c|c|c|c|c|c|c|c|}
\hline $\begin{array}{l}\text { Dependent Variable is } \\
\text { Headline Inflation Rate (s.a.) }\end{array}$ & Australia & Austria & Belgium & Canada & Finland & France & Germany \\
\hline \multicolumn{8}{|l|}{ Sum of Coefficients for } \\
\hline $\mathrm{U}$ & $\begin{array}{l}-0.11 \\
(0.15)\end{array}$ & $\begin{array}{l}-0.01 \\
(0.10)\end{array}$ & $\begin{array}{l}-0.16 \\
(0.16)\end{array}$ & $\begin{array}{l}-0.06 \\
(0.10)\end{array}$ & $\begin{array}{c}0.13 \\
(0.08)\end{array}$ & $\begin{array}{l}-0.02 \\
(0.11)\end{array}$ & $\begin{array}{l}-0.10 \\
(0.06)\end{array}$ \\
\hline$[\log (\mathrm{CPI})-\log ($ Mprice $)]$ & -- & -- & -- & -- & $\begin{array}{l}-0.04 \\
(0.01)\end{array}$ & -- & -- \\
\hline $\mathrm{R}^{2}$ & 0.43 & 0.31 & 0.34 & 0.72 & 0.87 & 0.27 & 0.69 \\
\hline SER (\% a.r.) & 3.41 & 1.72 & 1.44 & 1.12 & 1.99 & 1.54 & 1.50 \\
\hline $\begin{array}{l}\text { Residual Properties (p-values) }{ }^{\text {a }} \\
\text { Serial Independence } \\
\text { Homoskedasticity } \\
\text { Normality }\end{array}$ & $\begin{array}{l}0.45 \\
0.00 \\
0.10\end{array}$ & $\begin{array}{l}0.55 \\
0.98 \\
0.00\end{array}$ & $\begin{array}{l}0.39 \\
0.54 \\
0.92\end{array}$ & $\begin{array}{l}0.12 \\
0.46 \\
0.96\end{array}$ & $\begin{array}{l}0.19 \\
0.99 \\
0.05\end{array}$ & $\begin{array}{l}0.17 \\
0.53 \\
0.00\end{array}$ & $\begin{array}{l}0.06 \\
0.60 \\
0.23\end{array}$ \\
\hline \multicolumn{8}{|c|}{$\begin{array}{l}\text { a Entries correspond to the significance level to reject the associated hypothesis; an entry of } 0.05 \text { means that one } \\
\text { can reject the hypothesis with a } 5 \text { percent significance level. Serial Independence: F-test for the hypothesis that all } \\
\text { of the coefficients of an AR(5) for the residuals are equal to zero. Homoskedasticity: ARCH t-test. Normality: } \\
\text { Jarque-Bera chi-squared test. }\end{array}$} \\
\hline
\end{tabular}


Table A2: OLS Coefficient Estimates and Residual Properties for Standard Phillips Curve (continued) (standard errors in parentheses)

\begin{tabular}{|c|c|c|c|c|c|c|c|}
\hline $\begin{array}{l}\text { Dependent Variable is } \\
\text { Headline Inflation Rate (s.a.) }\end{array}$ & Greece & Ireland & Italy & Japan & Netherlands & $\begin{array}{c}\text { New } \\
\text { Zealand }\end{array}$ & Norway \\
\hline \multicolumn{8}{|l|}{ Sum of Coefficients for } \\
\hline $\mathrm{U}$ & $\begin{array}{l}-0.96 \\
(0.50)\end{array}$ & $\begin{array}{c}0.76 \\
(0.35)\end{array}$ & $\begin{array}{c}-0.16 \\
(0.18)\end{array}$ & $\begin{array}{l}-0.40 \\
(0.70)\end{array}$ & $\begin{array}{l}-0.03 \\
(0.09)\end{array}$ & $\begin{array}{l}-2.24 \\
(1.00)\end{array}$ & $\begin{array}{l}-0.07 \\
(0.17)\end{array}$ \\
\hline$[\log (\mathrm{CPI})-\log ($ Mprice $)]$ & $\begin{array}{l}-0.44 \\
(0.14)\end{array}$ & $\begin{array}{l}-0.07 \\
(0.03)\end{array}$ & -- & -- & -- & $\begin{array}{l}-0.28 \\
(0.18)\end{array}$ & -- \\
\hline $\mathrm{R}^{2}$ & 0.44 & 0.51 & 0.32 & 0.40 & 0.33 & 0.75 & 0.32 \\
\hline SER (\% a.r.) & 3.53 & 4.29 & 3.14 & 2.82 & 1.57 & 4.18 & 2.55 \\
\hline Residual Properties (p-values) & & & & & & & \\
\hline Serial Independence & 0.94 & 0.54 & 0.95 & 0.19 & 0.81 & 0.86 & 0.73 \\
\hline Homoskedasticity & 0.72 & 0.00 & 0.48 & 0.00 & 0.95 & 0.22 & 0.52 \\
\hline Normality & 0.12 & 0.08 & 0.01 & 0.00 & 0.61 & 0.05 & 0.00 \\
\hline
\end{tabular}

${ }^{a}$ Entries correspond to the significance level to reject the associated hypothesis; an entry of 0.05 means that one can reject the hypothesis with a 5 percent significance level. Serial Independence: F-test for the hypothesis that all of the coefficients of an AR(5) for the residuals are equal to zero. Homoskedasticity: ARCH t-test.

Normality: Jarque-Bera chi-squared test.

$\mathrm{U}$ : Unemployment rate

P: Level of headline CPI

Mprice: Level of import prices 
Table A2: OLS Coefficient Estimates and Residual Properties for Standard Phillips Curve (continued) (standard errors in parentheses)

\begin{tabular}{|c|c|c|c|c|c|c|}
\hline $\begin{array}{l}\text { Dependent Variable is } \\
\text { Headline Inflation Rate (s.a.) }\end{array}$ & Portugal & Spain & Sweden & Switzerland & UK & US \\
\hline Sum of Coefficients for & & & & & & \\
\hline $\mathrm{U}$ & $\begin{array}{l}-0.86 \\
(0.31)\end{array}$ & $\begin{array}{l}-0.02 \\
(0.07)\end{array}$ & $\begin{array}{l}-1.27 \\
(0.50)\end{array}$ & $\begin{array}{l}-0.02 \\
(0.23)\end{array}$ & $\begin{array}{c}0.20 \\
(0.10)\end{array}$ & $\begin{array}{l}-0.411 \\
(0.19)\end{array}$ \\
\hline$[\log (\mathrm{CPI})-\log ($ Mprice $)]$ & -- & -- & -- & -- & -- & $\begin{array}{c}0.001 \\
(0.004)\end{array}$ \\
\hline $\begin{array}{l}\mathrm{R}^{2} \\
\text { SER (\% a.r.) }\end{array}$ & $\begin{array}{l}0.55 \\
3.61\end{array}$ & $\begin{array}{l}0.47 \\
2.05\end{array}$ & $\begin{array}{l}0.54 \\
3.38\end{array}$ & $\begin{array}{l}0.26 \\
2.20\end{array}$ & $\begin{array}{l}0.81 \\
1.93\end{array}$ & $\begin{array}{l}0.61 \\
1.46\end{array}$ \\
\hline $\begin{array}{l}\text { Residual Properties (p-values) }{ }^{\text {a }} \\
\text { Serial Independence } \\
\text { Homoskedasticity } \\
\text { Normality }\end{array}$ & $\begin{array}{l}0.19 \\
0.38 \\
0.54\end{array}$ & $\begin{array}{l}0.33 \\
0.99 \\
0.25\end{array}$ & $\begin{array}{l}0.58 \\
0.43 \\
0.00\end{array}$ & $\begin{array}{l}0.93 \\
0.57 \\
0.00\end{array}$ & $\begin{array}{l}0.67 \\
0.95 \\
0.00\end{array}$ & $\begin{array}{l}0.53 \\
0.84 \\
0.64\end{array}$ \\
\hline
\end{tabular}

${ }^{a}$ Entries correspond to the significance level to reject the associated hypothesis; an entry of 0.05 means that one can reject the hypothesis with a 5 percent significance level. Serial Independence: F-test for the hypothesis that all of the coefficients of an $\mathrm{AR}(5)$ for the residuals are equal to zero. Homoskedasticity: ARCH t-test. Normality: Jarque-Bera chi-squared test.

U: Unemployment rate

P: Level of headline CPI

Mprice: Level of import prices 